\title{
Importance of mangrove carbon for aquatic food webs in wet-dry tropical estuaries
}

\author{
Kátya G Abrantes ${ }^{\mathrm{a}, \star}$, Ross Johnston ${ }^{\mathrm{a}}$, Rod M Connolly ${ }^{\mathrm{b}}$, Marcus Sheaves ${ }^{\mathrm{a}}$
}

${ }^{a}$ Centre for Tropical Water and Aquatic Ecosystem Research, Estuary and Tidal Wetland Ecosystems Research Group, School of Marine and Tropical Biology, James Cook University, Townsville, QLD 4811, Australia

b Australian Rivers Institute - Coast and Estuaries, and School of Environment, Gold Coast campus, Griffith University, QLD 4222, Australia

* Corresponding author: Katya.Abrantes@gmail.com

\begin{abstract}
Mangroves are traditionally considered to provide important nutrition to tropical estuarine consumers. However, there is still controversy about this, and the extent and importance of these inputs is largely unquantified. In particular, there is no information for food webs of small estuaries that dominate wet-dry tropical coasts, where freshwater inflow is intermittent, leading to highly seasonal inputs of nutrients from terrestrial systems. Since the relative importance of the different sources depends on the type and extent of different habitats and on hydrological and topographic conditions, results from other regions/type of systems can not be extrapolated to these estuaries. Here, $\delta^{13} \mathrm{C}$ is used to determine the importance of mangrove-derived carbon for Penaeus merguiensis (detritivore; shrimp), Ambassis vachellii (planktivore; fish) and Leiognathus equulus (benthivore; fish) from six small wet-dry tropical estuaries that differ in mangrove $\left(\mathrm{C}_{3}\right)$ cover and in type of terrestrial vegetation adjacent to the estuary. Bayesian mixing models confirmed that mangrove material was important to consumers in all estuaries. There was a gradient in this importance that agreed with the extent of mangrove forests in the
\end{abstract}


estuaries, as $\mathrm{C}_{3}$ sources were the most important contributors to animals from the three estuaries with the greatest (>40\%) mangrove cover. There was also evidence of incorporation of $\mathrm{C}_{3}$ material for the three estuaries with lower (<30\%) mangrove cover. Since these latter estuaries had no adjacent terrestrial $C_{3}$ forests, the detected $C_{3}$ influence can only be of mangrove origin. This shows that mangroves are important contributors to these food webs, underlining the importance of mangroves in supporting estuarine nursery ground value and fisheries productivity.

Keywords: Bayesian mixing models; $\delta^{13} \mathrm{C}$, estuaries; food webs; mangroves; stable isotope analysis. 


\section{Introduction}

The availability of adequate food and nutrients is vital to sustain the natural dynamics of biotic communities. In estuarine systems, animal communities generally rely on a combination of aquatic (autochthonous) and terrestrial (allochthonous) sources, with the importance of each source depending on the relative availability of material from the different origins (Polis et al. 1997, Bouillon et al. 2004, Abrantes et al. 2013). Given the present trend of increasing modification of estuaries and their catchments throughout the world (Lotze et al. 2006, Sheaves et al. 2014) it is crucial to understand the relative importance of these contrasting sources for estuarine consumers. However, the balance of contributions from different sources is still poorly resolved for many systems, especially in the tropics; while some studies suggest that terrestrial and mangrove/saltmarsh material can be important (e.g. Wai et al. 2011, Abrantes et al. 2013), others have failed to find evidence of incorporation of mangrove/saltmarsh or adjacent terrestrial vegetation, and suggest that estuarine food webs are based on more easily assimilated aquatic producers (e.g. Chanton \& Lewis 2002, Lin et al. 2007).

Although some research has been done for estuaries of large tropical rivers (e.g. Chanton \& Lewis 2002, Abrantes et al. 2013), small perennial rivers in the wet tropics (e.g. Chong et al. 2001, Nyunja et al. 2009), near-pristine mangrove areas (Abrantes et al. 2009a) and semi-isolated estuarine floodplain pools (e.g. Abrantes \& Sheaves 2008, Abrantes \& Sheaves 2010), information on the main sources of nutrition supporting consumers in the small estuaries that dominate wet-dry tropical coasts is still lacking. Given the widespread distribution of these systems, this presents a serious knowledge gap. The wet-dry climate is characterized by distinct wet and dry seasons, with most annual rainfall occurring during the wet season, and very little falling during the dry season. Wet-dry tropical climate covers the coasts of most of northern Australia (from Central Queensland to northern Western Australia), eastern India, parts of Indo-China, eastern (Kenya to Mozambique and Madagascar) and western Africa (Senegal to Angola), Central (mostly in the western coast), Southern (parts of Brazil, Venezuela and Colombia) and North America (parts of southern Mexico and Caribbean Islands) (Peel et al. 2007). Because there is considerable variation in assemblage structure (Sheaves et al. 2009) and because trophic processes in the different regions/types of systems are likely to differ 
greatly depending on factors such as size, connectivity regimes, area of drainage basins, productivity of terrestrial and aquatic environments and type and extent of adjacent vegetation (Abrantes et al. 2013), results from one region or one type of system can not be extrapolated to other regions/systems without local validation.

Small estuaries are ubiquitous in the Australia's wet-dry tropics (Erskine et al. 2005, Sheaves et al. 2010), providing important feeding, spawning and nursery habitats for a range of fish and invertebrates, many of recreational and/or economic importance (Beck et al. 2001, Dahlgren et al. 2006). Despite their small size and small catchments, these estuaries contribute disproportionately to coastal ecosystem functioning due to their prevalence and because they are generally less impacted by human activities than larger systems. Nevertheless, they are often subjected to specific local-scale impacts such as land-fill to convert mangrove areas to agricultural land and construction of barriers that restrict tidal/freshwater flows and limit connectivity of organic matter and animals between habitats (e.g. bund walls, levees, roads) (Boys et al. 2012).

Stable isotope analysis of carbon $\left(\delta^{13} \mathrm{C}\right)$ is commonly used to study the importance of terrestrial vs. aquatic sources for estuarine food webs (e.g. Peterson et al. 1986, Bouillon et al. 2011). This is because different primary producers can have different $\delta^{13} \mathrm{C}$ ratios (France 1996), and because $\delta^{13} \mathrm{C}$ undergoes a small and predictable change from food source to consumer ( $0-$ 1\%; DeNiro \& Epstein 1978, McCutchan et al. 2003). However, estuarine producers can be spatially and/or temporarily variable in $\delta^{13} \mathrm{C}$ values (Cloern et al. 2002, Guest et al. 2004), $\delta^{13} \mathrm{C}$ of dissolved inorganic carbon (DIC) can affect the $\delta^{13} \mathrm{C}$ of aquatic producers (Bouillon et al. 2008), and it can be methodologically difficult to appropriately sample aquatic producers such as phytoplankton and microphytobenthos (MPB), especially in turbid environments, meaning care is needed in the interpretation of stable isotope results.

We investigated $\delta^{13} \mathrm{C}$ contributions to consumers in 6 estuaries in the wet-dry tropics of northern Australia to determine the relative importance of mangrove and terrestrial producers to the productivity of small wet-dry tropics estuaries. Systems surrounded by different combinations of mangrove forests and terrestrial vegetation with different mixes of $C_{3} / C_{4}$ plants 
provided an ideal situation to study the contribution of mangroves, because $\mathrm{C}_{3}$ and $\mathrm{C}_{4}$ sources are well separated in $\delta^{13} \mathrm{C}(\sim-27 \%$ vs. $\sim-12 \%$ ) (Cerling et al. 1997). However, it can be difficult to differentiate contributions of organic matter imported from forests in the catchments from that of adjacent mangrove forests based on $\delta^{13} \mathrm{C}$ alone, as both types of vegetation possess the same photosynthetic pathway $\left(\mathrm{C}_{3}\right)$ and are therefore characterized by similar $\delta^{13} \mathrm{C}$ values. However, this complexity was used to advantage in the present study, as the systems considered have very small catchments and are subjected to short (2-3 months), well defined wet seasons separated by long dry seasons, when freshwater flow is mostly absent (Finlayson \& McMahon 1988). Consequently, they can receive terrestrial organic matter from the catchment for only 2-3 months of the year while for most of the year there is minimal potential for input of this material. Any incorporation of $\mathrm{C}_{3}$ material detected at the end of the dry season is therefore likely to be of mangrove origin, rather than from adjacent terrestrial forests. Comparisons of contributions of $\mathrm{C}_{3}$ sources between dry and wet seasons thus gives further information on the input of mangrove vs. terrestrial material from the catchments.

\section{Methods}

\section{Study Sites}

The estuaries of six creeks spanning $\sim 120$ km of North Queensland's wet-dry tropics (Australia) were sampled: Sandfly, Cocoa, Doughboy, Crab, Mud and Hell Hole Creeks (Fig. 1). These creeks are typical of the region: they are relatively short (<10 km navigable length) and narrow, with maximum mouth widths between $25-60 \mathrm{~m}$, narrowing down to 5-15 $\mathrm{m}$ at the upper limits of navigation. All systems are tide dominated, with tidal incursions ranging between 2 and $5 \mathrm{~km}$. Tides are semi-diurnal with a maximum range of $\sim 4 \mathrm{~m}$. Depths at low tide are typically $\sim 3.5 \mathrm{~m}$ closer to the mouth, decreasing with distance upstream until the limits of navigation. The substrates are dominated by sand and mud. Macroalgae are very rare and seagrass only occurs in the mouths of Cocoa and Crab Creeks. The climate of the area is characterised by a short rainy season from December to March and a long dry season from April to November (Fig. 
2), when there is little or no freshwater inflow from intermittent feeder streams, leading to strong seasonality in potential inputs of nutrients from terrestrial systems.

Mangrove forests occur at the lower reaches of all estuaries, with a mangrove fringe at least $5 \mathrm{~m}$ wide also present through most of their length. Saltmarshes (dominated by the $\mathrm{C}_{4}$ grass Sporobolus virginicus) and saltpans sometimes occur adjacent to the mangrove forests, in the upper intertidal. These areas are generally flooded only on the highest spring tides, and for relatively short periods. In Doughboy, Mud, and Hell Hole Creeks, surrounding vegetation is mostly mangrove and terrestrial forests, whereas at Crab and Sandfly Creeks the adjacent area is dominated by $\mathrm{C}_{4}$ producers (Table 1 ), mostly saltmarsh plants but also including pasture grass and, in Sandfly Ck, limited horticulture. In Cocoa Ck, the surrounding area is dominated by saltflats (Table 1). Cocoa and Sandfly Creeks have U-shaped cross-channel profiles with steep banks that provide little area for benthic microalgae production; Crab Ck has a slightly larger intertidal area, followed by Doughboy $\mathrm{Ck}$, which has areas of intertidal banks (up to $\sim 3 \mathrm{~m}$ wide) suitable for benthic productivity. Hell Hole and Mud Creeks are shallower, with large intertidal areas, and Mud Ck has the largest intertidal area of all estuaries (Table 1).

\section{Sample collection and analysis}

Juveniles of two fish and one penaeid prawn species were sampled at each estuary in mid March 2008, just after the 2007/08 wet season, and again in mid November 2008, at the end of the dry season (to represent carbon accumulated during the wet and dry season respectively). The only exception was Sandfly $\mathrm{Ck}$, which could not be sampled in the wet season due to local flooding. Species considered were the Vachell's glassfish Ambassis vachellii, the common ponyfish Leiognathus equulus and the banana prawn Penaeus merguiensis. A. vachellii is an estuarine spawner, and individuals captured were likely to have spent their whole life in the estuary of capture, Leiognathus equulus and $P$. merguiensis are offshore spawners, with juveniles (L. equulus) or postlarvae (P. merguiensis) recruiting into estuaries at small sizes ( $<20$ $\mathrm{mm}$ for L. equulus (Sheaves et al. 2013); $<3 \mathrm{~mm}$ carapace length for P. merguiensis (Haywood \& Staples 1993)) early in the pre-wet season, so animals collected would likely have spent a 
minimum of a few months in the systems before both sampling occasions (Robertson \& Duke 1990, Haywood \& Staples 1993).

Penaeus merguiensis juveniles are mostly detritivores, feeding on large amounts (up to $75 \%$ ) of flocculent detritus (including mangrove material) and also on small invertebrates such as crustaceans (ostracods, calanoid copepods, brachyuran larvae) and gastropods (Robertson 1988). Ambassis vachellii feeds mostly on planktonic crustaceans such as decapoda larva, copepods and amphipods (Wilson \& Sheaves 2001). Leiognathus equulus juveniles have a more benthic-associated diet, feeding mostly on small benthic prey (harpacticoid copepods, gammarid amphipods, gastropods, bivalves, polychaetes) and to a lesser extent on pelagic prey such calanoid copepods (Wilson \& Sheaves 2001, Mavuti et al. 2007).

These three species were selected because they are abundant and ubiquitous in Australia's wet-dry tropics estuaries (Sheaves \& Johnston 2010, Sheaves et al. 2012), represent contrasting trophic pathways, and because they are fast growing (Robertson \& Duke 1990, Haywood \& Staples 1993), meaning that their stable isotope composition should accurately reflect the diet over the last 1-2 months. After a change in diet, it takes some time for the isotopic composition of consumers to reflect the new diet, depending both on growth and on metabolism. For muscle of small $(<5 \mathrm{~g})$, growing fish and invertebrates such as those used in the present study, carbon half-lives are less than one month (Guelinckx et al. 2007, Weidel et al. 2011). Thus, the stable isotope composition of these animals provides time-integrated information on the most important sources of nutrition for food webs at each estuary, and the -3.5 month time lag between the beginning of the 2007/08 wet season and the March 2008 sampling, and the -8 month time lag between the end of the 2007/08 wet season and the November 2008 sampling (see Fig. 2) means that the $\delta^{13} \mathrm{C}$ values of animals at the times of capture will reflect their diet in wet and dry conditions respectively.

Animals were captured with a $5 \mathrm{~mm}$ mesh monofilament drawstring cast net deployed from a small boat. Sampling was done over the low tide period, when mangrove forests were drained and animals forced into the channels. Each estuary was sampled at its lower (close to the mouth), mid and upper reach (close to the limit of saltwater intrusion). Whenever possible, 
15 individuals of each species (of similar sizes) were collected from each reach. Samples were stored frozen until processing. Salinity and turbidity were also measured on each sampling occasion. Salinity was measured using an optical salinometer (accuracy $\sim 1$ ) and turbidity with a TPS WP-88 handheld turbidity meter (accuracy $\sim 1$ NTU). Instruments were referenced to standards before each sampling trip. In the laboratory, animals were identified and measured (standard length for fish; total length for prawns), and white muscle tissue was excised from the trunk below the dorsal fin of fish and from the abdominal muscle of prawns. Samples were then dried for $48 \mathrm{~h}$ at $60^{\circ} \mathrm{C}$ and homogenized into a fine powder with a mortar and pestle. For each species, similar amounts (by weight) of dried tissue from each of the individuals collected at each reach/estuary were combined into a single sample to reduce the effect of intraspecific variability providing the best possible estimate of carbon isotopic composition of a species in each sample (Lancaster \& Waldron 2001). This material was then homogenised by manually shaking the vials and $\sim 0.1 \mathrm{~g}$ was subsequently weighed into $8 \times 5$ tin capsules. The carbon stable isotope composition of each sample was measured with an Isoprime isotope ratio mass spectrometer (IRMS) coupled with an element analyzer. Results are expressed as per mil

(\%) deviations from the standards, as defined by the equation: $\delta^{13} \mathrm{C}=\left[\left(\delta^{13} \mathrm{C}\right.\right.$ sample $\left./ \delta^{13} \mathrm{C}_{\text {reference }}\right)$ - 1] $\times 10^{3}$, and had a precision of $\pm 0.1 \%$ o (SD), calculated from multiple runs of the same prawn and flour samples. No corrections for lipid content were made as $\mathrm{C}: \mathrm{N}$ ratios of all samples were $<3.5$ (Post et al. 2007).

\section{Data analysis}

For each estuary, Bayesian mixing models were used to quantify the contribution of the main classes of producers to each species, using SIAR (Stable Isotope Analysis in R; Parnell et al. 2010). Because the stable isotope composition of animals from the three reaches within an estuary often differed, models were run for each reach separately. Since generally only one sample (composed of up to 15 individuals, pooled) was available for each reach, the SIARSOLO command was used (Parnell et al. 2010). In some cases, however, two or three composite samples were available for the same reach and season, in which cases $\delta^{13} \mathrm{C}$ results were 
averaged (arithmetic mean) between samples and the mean used in the model. Bayesian mixing models produce a range of solutions given the available sources while taking into account uncertainty and variation in consumer stable isotope composition and trophic enrichment factors (TEF). $\mathrm{A} \delta^{13} \mathrm{C}$ TEF of $1.0 \%$ was used, while taking into account the different species' trophic level, as appropriate for non acid-treated muscle tissue (McCutchan et al. 2003), and a TEF standard deviation (SD) of $1.5 \%$ was used to account for the uncertainty in this value (Vander Zanden \& Rasmussen 2001, McCutchan et al. 2003, Caut et al. 2009). Penaeus merguiensis juveniles were considered to be of trophic level 2.5 (Robertson 1988, Abrantes \& Sheaves 2009b), and A. vachellii and L. equulus juveniles of trophic level 3 (Wilson \& Sheaves 2001, Mavuti et al. 2007). Concentration dependencies were set to zero. Because SIAR is sensitive to variation in discrimination factors (Bond \& Diamond 2011), a sensitivity analysis was done in which additional models were run using TEFs of $0 \%$ and $2 \%$, to determine if different scenarios would lead to different final results regarding contribution of $\mathrm{C}_{3}$ sources.

Potential sources considered were $\mathrm{C}_{3}$ producers (which include mangroves), $\mathrm{C}_{4}$ producers (which include saltmarsh), plankton and microphytobenthos (MPB). For Cocoa and Crab Creeks, seagrass was also considered as a potential source, as seagrass beds occur in the mouths of these estuaries. Primary producers were not collected, so the $\delta^{13} \mathrm{C}$ values used in the models were based on data from similar systems of the region or data from the literature. For plankton, the $\delta^{13} \mathrm{C}$ value used was $-20.5 \%$ and for MPB a value of $-14.0 \%$ was used, based on the average $\delta^{13} \mathrm{C}$ of plankton/MPB collected from 15 small estuaries spanning over $600 \mathrm{~km}$ of the wet-dry tropical Queensland coast (own unpubl. data). For seagrass, the average value of $-11.5 \%$ was considered, based on the review by Hemminga \& Mateo (1996) on the variability in seagrass $\delta^{13} \mathrm{C}$. For $\mathrm{C}_{3}$ sources, a $\delta^{13} \mathrm{C}$ of $-27 \%$ was used, and for $\mathrm{C}_{4}$ sources $-12 \%$ was used (Cerling et al. 1997). Because these values were taken from other studies, large source SDs of $2 \%$ were used to account for the uncertainty. For MPB a larger SD of $\pm 3 \%$ was used, as MPB can have a relatively large variability in $\delta^{13} \mathrm{C}$ in North Queensland estuaries (own unpubl. data). These large source SDs, coupled with the large TEF SDs used (1.5\%), should lead to conservative results regarding the importance of the different sources. Note that even if source values are not precise, all models were calculated based on the same values so results will be 
comparable among the sites. Because only one element was used and the number of sources was 4-5, we did not expect to be able to distinguish between the contributions of all sources. However, our aim was to identify and quantify the importance of $\mathrm{C}_{3}$ mangroves, and since $\mathrm{C}_{3}$ producers are well separated from the remaining sources, their contribution can be estimated with confidence, especially since the three consumer species often had $\delta^{13} \mathrm{C}$ that could only be explained by some contribution of $\mathrm{C}_{3}$ sources.

The proportion of mangrove forests, terrestrial forests, $\mathrm{C}_{4}$-dominated vegetation (including saltmarsh and cattle pastures), saltpan and savanna vegetation (mix of $\mathrm{C}_{3}$ and $\mathrm{C}_{4}$ vegetation) in the area adjacent to each estuary were estimated using SigmaScan Pro, based on freely available images from Google Earth and supported by detailed ground truthing. Because the catchments of these systems have not been delineated, the percentage of vegetation types within $1 \mathrm{~km}$ of estuary margins was considered as indicative of adjacent available producers. To help separate contributions of carbon from mangrove origin from that of terrestrial $\mathrm{C}_{3}$ forests, the effects of the relative mangroves cover and of overall $\mathrm{C}_{3}$ cover (includes both mangroves and $\mathrm{C}_{3}$ terrestrial forests) on the contribution of $\mathrm{C}_{3}$ sources to consumers were modeled for each species and season using multiple regression models with backward elimination. The aim was to determine the extent to which contribution of $\mathrm{C}_{3}$ sources (\%; based on Bayesian mixing models) (dependent variable) can be explained by mangrove cover alone, and whether total $\mathrm{C}_{3}$ cover (i.e. including also terrestrial forests) provides more explanatory power.

Classification and regression tree analyses (CARTs; De'ath \& Fabricius 2000) were used to explain the extent to which the importance of $\mathrm{C}_{3}$ sources depends on estuary, reach, species and season. Input data were the modal contributions of $\mathrm{C}_{3}$ sources for each group (Parnell et al. 2010). CART analysis is robust non-parametric test that successively splits the dataset into two relatively homogeneous and mutually exclusive groups based on minimising the within-group sum of square residual deviation. The trees are represented in a graphical way, with the root node on top, representing the initial assemblage of data, from which the branches and leaves 
emerge. Splits close to the node are more important than those at the bottom of the tree, providing greater improvement to the fit of the model. The relative lengths of the vertical lines associated with each split gives indication of the proportion of the total sum of squares explained by each split. The size of the tree (or number of leaves), corresponding to the final number of groups, was selected by 10 -fold cross-validation and the 1-SE tree, i.e. the smallest tree with cross validation error within 1 SE of the tree with the minimum cross validation error, was selected as the final tree model (De'ath \& Fabricius 2000). Analyses were conducted using the TREES Plus package (De'ath \& Fabricius 2000). Because not all species occurred at all reaches and at all seasons, and this could hinder the identification of seasonal effects by the CART, seasonal differences in importance of $\mathrm{C}_{3}$ sources were further investigated for pairs of species that occurred in the same estuary and same reach for both seasons. Although wet season samples were collected before the dry samples, in March and November 2008 respectively, results are presented as changes in $\mathrm{C}_{3}$ contribution from the wet-dry to the wet season, to facilitate interpretation of the effect of the wet season. The presence of seasonal shifts in importance of $\mathrm{C}_{3}$ sources was tested using CART analysis where the dependent variable was the difference in mode of contribution between seasons, and the independent variables were species, estuary, reach and season. The input data consisted of zeroes for the dry season, i.e. the starting point against which the effect of the wet season was measured, and input values for the wet season corresponded to the differences in mode of contribution between the two seasons. A split between seasons with zero in the dry and the difference in mode contribution in the wet season would indicate a significant seasonal change in importance of $\mathrm{C}_{3}$ sources, while the lack of a split would indicate that the importance $\mathrm{C}_{3}$ sources was similar for the two seasons.

\section{Results}

Environmental parameters. For all estuaries, salinities were lower during the wet season than in the dry season (Table 1). In the wet season, salinities were generally similar and close to sea water in with the exception of Hell Hole, where waters were less saline (16-18). Within each 
estuary, salinities did not vary by much between the lower and upper reaches (maximum difference between reaches only 4; Table 1). In the dry season, however, salinities were higher than seawater for all estuaries (range: 37-47). The greatest difference in salinity between upper and lower reaches occurred in Cocoa $\mathrm{Ck}$ (difference of 8), while for the remaining estuaries the upstream-downstream differences were $<5$. In general, salinities were higher at the upper reaches than at the lower reaches, with the exception of Doughboy Ck (similar salinity at both reaches) and Hell Hole Ck (salinity at lower reach higher than at upper reach). There were often differences in turbidity between the lower and upper reaches (Table 1). Wet season turbidities varied between lower reaches of estuaries, with clearer waters in Hell Hole and Mud Creeks (25 and 26 NTU respectively), intermediate turbidity in Cocoa and Doughboy Creeks (78 and 72 NTU respectively) and a maximum of 121 NTU at Crab Ck. In the upper reaches, turbidity levels were low and more similar between estuaries, ranging from 18 and 43 NTU. In the dry season, turbidities were similar among estuaries and generally low, between 8 and 30 NTU in the lower reaches and between 17 and 56 NTU in the upper reaches (Table 1).

Animal $\delta^{13} \mathrm{C}$ and mixing model results. For all three species, there were differences in $\delta^{13} \mathrm{C}$ between estuaries and between seasons (Table 2, Fig. 3). In general, animals from Mud, Doughboy and Hell Hole Creeks had the lowest $\delta^{13} \mathrm{C}$ values, and those from Cocoa, Crab and Sandfly Creeks the highest (Fig. 3). In the wet season, all three species had relatively similar $\delta^{13} \mathrm{C}$ values within each estuary, but in the dry season the three species often differed in $\delta^{13} \mathrm{C}$ (Fig. 3). Moreover, while the $\delta^{13} \mathrm{C}$ values of a species were similar for the three reaches during the wet season, in the dry season those values generally differed between reaches, often by more than 3\% (Fig. 3). Accordingly, mixing model results show that, within each estuary, the three species depended on a similar combination of sources in the wet season, while in the dry season the three species reliance on the different sources varied (Fig. 4; Electronic Supplements 1 and 2). Additionally, for each species, the contribution of the different sources was similar between reaches for the wet season, but generally differed between reaches in the dry season (Fig. 4; Electronic Supplements 1 and 2). 
Mixing models based on different TEFs (0\%, $1 \%$ and $2 \%$ ) lead to similar patterns of spatial and temporal variability in importance of $\mathrm{C}_{3}$ sources for the three species. Overall, $\mathrm{C}_{3}$ material was an important source for the three species in all estuaries, but this importance varied between estuaries, reaches, seasons and species (Electronic Supplement 1 and 2). For example, when considering a TEF of $1 \%, C_{3}$ contributions varied from $5-41 \%$ (95\% credibility interval $(C l))$ for $P$. merguiensis from the downstream reaches of Cocoa $C k$, to $70-97 \%$ for $L$. equulus at the upstream reach of Mud Ck (Fig. 4; Electronic Supplements 1 and 2). Models run using TEFs of $0 \%$ and $2 \%$ o led to similar results: $C_{3}$ contribution was the lowest for $P$. merguiensis from the downstream reaches of Cocoa Ck $(95 \% \mathrm{Cl}=1-24 \%$ and 10-48\%o when considering TEFs of $0 \%$ and $2 \%$ respectively), and the highest for $L$. equulus at the upstream reach of Mud Ck (95\% Cl = 58-95\%o and 76-98\%) (Electronic Supplement 2).

In general, $\mathrm{C}_{3}$ sources were the most important contributors for animals in the three estuaries with the highest mangrove cover (Doughboy, Hell Hole and Mud Creeks), while in estuaries with lower mangrove cover (Cocoa, Crab and Sandfly Creeks) animals relied on a more balanced combination of terrestrial and aquatic sources, including benthic and planktonic algae (Electronic Supplements 1 and 2). In these latter estuaries, when considering a TEF of $1 \%$, $\mathrm{C}_{3}$ sources contributed to all species in all reaches, with lower bounds of the $95 \% \mathrm{Cl} \geq 10 \%$ in 29 out of the 37 cases, $>20 \%$ in 9, and >30\% in two cases (Electronic Supplements 1 and 2). When considering a TEF of $0 \%$, the lower bounds of the $95 \% \mathrm{Cl}$ were $>10 \%$ for 14 out of the 37 cases (>20\% in two cases), and for models run using TEFs of $2 \%$, lower bounds of the $95 \% \mathrm{Cl}$ were $>10 \%$ in 26 out of the 27 cases $(>20 \%$ in 22 cases and $>30 \%$ in five cases) (Electronic Supplement 2).

For both seasons, there were positive relationships between the relative area of mangrove cover (in \%) and the modal contribution of $\mathrm{C}_{3}$ sources for the three species (Table 3; Fig. 4). These relationships were present when models were run using TEFs of 0\%, $1 \%$ and 2\%o (Table 3). Backwards multiple linear regressions show that mangrove cover was the most important factor explaining the importance of $\mathrm{C}_{3}$ sources to consumers, and that including terrestrial $\mathrm{C}_{3}$ forest cover (to make total $\mathrm{C}_{3}$ cover) in the models did not improve explanatory power in any case (Table 3). The only exception was for $A$. vachellii in the dry season, for which 
no effect of mangrove or total $\mathrm{C}_{3}$ cover was detected for models run using a TEF of $0 \%$, as all variables were removed from the regression equation (Table 3).

For the CART analyses, models run using TEFs of $0 \%$, $1 \%$ and $2 \%$ led to similar results (Fig. 5). In the three cases, four-leaf CARTs, explaining 63\%, 59\% and 65\% of the total variability respectively, indicate that the contribution of $\mathrm{C}_{3}$ sources is primarily dependent on estuary, as material of $\mathrm{C}_{3}$ origin was more important for consumers in Doughboy, Hell Hole and Mud Creeks, the estuaries with higher (>40\%) mangrove cover, than in Cocoa, Sandfly and Mud Creeks, the estuaries with lower (<30\%) mangrove cover (Fig. 5). This first split in the data explained most of the total variability: for the model run using a TEF of $0 \%$, it explained $46 \%$ of the variability, while for the models run on TEF of $1 \%$ and $2 \%$ it explained $45 \%$ and $50 \%$ respectively. Although there were small differences between models in the lower branches of the trees, the three models agree that for the three creeks with highest mangrove cover (Doughboy, Hell Hole and Mud Creeks), the contribution of $C_{3}$ sources was greater for $L$. equulus than for $P$. merguiensis and $A$. vachellii (Fig. 5).

There was also evidence of seasonal differences in importance of $C_{3}$ sources, although this varied between species (Fig. 6). CARTs based on solutions of the mixing models run using different TEFs led to similar results. When a TEF of $0 \%$ was used in the mixing models, the resulting three-leaf CART indicates a significant effect of season but only for $L$. equulus, for which the importance of $\mathrm{C}_{3}$ sources was greater in the dry season than in the wet season (Fig. 6a). CARTs based on mixing models with higher TEFs of $1 \%$ and $2 \%$ also showed a similar effect for $A$. vachellii, while for $P$. merguiensis $C_{3}$ sources were generally more important in the wet season, especially for the mid and lower reaches of estuaries (Fig. 6a,b) where the largest mangrove areas were generally present and regularly submerged. Therefore, while for the two fish species the importance the importance of $\mathrm{C}_{3}$ sources was greater in the dry season, for the prawn species $\mathrm{C}_{3}$ sources were more important in the wet season. 


\section{Discussion}

\section{Importance of mangrove carbon for estuarine food webs}

In general, results indicate that $C_{3}$ material is important for aquatic food webs in small wet-dry tropical estuaries. However, this importance differs between systems, depending on the type and extent of adjacent vegetation. $\mathrm{C}_{3}$ contribution is correlated with the relative extent of mangrove forests at each estuary, and adding the terrestrial $\mathrm{C}_{3}$ forest cover to the models did not provide greater explanatory power in any case, suggesting that mangroves, rather than terrestrial forests in the adjacent area, were the main sources of $\mathrm{C}_{3}$ carbon for consumers in these systems. Indeed, even for Sandfly, Cocoa and Crab Creeks, where terrestrial forests are absent, mangrove forests covered $<30 \%$ of the adjacent area, and where $\mathrm{C}_{4}$ vegetation (including saltmarsh, pasture land and sugarcane plantations) and saltflats dominated the adjacent area, $\mathrm{C}_{3}$ carbon was still important for consumers, with mode contributions always $\geq 25 \%$ and lower bounds of the $95 \% \mathrm{Cls}>5 \%$ in all but one case, when considering TEF 1\%o for example (see Electronic Supplement 1).

For all sites, $\mathrm{C}_{3}$ sources had some importance for all species even in November 2008, eight months after the end of the previous wet season, further indicating that even for the estuaries where adjacent $C_{3}$ forests are present, this $C_{3}$ input was from mangrove productivity rather than from forests in the adjacent catchment. Indeed, the minimal rainfall during the 2008 dry season (see Fig. 2) was unlikely to be sufficient to transport significant amounts of $\mathrm{C}_{3}$ terrestrial organic material into the waterways. The small catchments of these estuaries and little, if any, freshwater inflow during most of the year (Sheaves 1996) also limits the possibility that any substantial material from the upstream catchment is imported into the estuary. Although mangrove carbon is considered to be of poor nutritional quality, tropical mangrove forests are highly productive and high quantities of nutrients, organic matter and mangrove litter regularly enter these systems (Jennerjahn \& Ittekkot 2002, Kristensen et al. 2008). Several invertebrate and fish species, including the species considered in the present study, move into mangrove forests at high tides for food and protection (Vance et al. 1996, Sheaves \& Molony 2000). The 
relative importance of mangroves can be further increased in small estuaries such as those from the present study as these are narrow, with high ratios of mangrove area to open water area (Robertson \& Blaber 1992). Thus, the often $>50 \%$ modal contribution of $\mathrm{C}_{3}$ sources in the three estuaries with higher mangrove cover, even in the dry season and even when a TEF of 0\% was considered, indicates that mangroves can be the main sources of nutrients supporting food webs in these systems. If levels of aquatic productivity are similar for systems with and without extensive mangrove forests, it is likely that estuaries with larger areas of mangrove forests can fuel more abundant consumer communities.

\section{Sensitivity analysis and other considerations}

The use of different TEFs (0\%, $1 \%$ and $2 \%$ ) in the Bayesian mixing models led to similar patterns of spatial and temporal variation in importance of $\mathrm{C}_{3}$ sources for the three consumer species. This sensitivity analysis confirms that there is an incorporation of $\mathrm{C}_{3}$ material by these estuarine species, and that there is seasonality in this importance, although results based on TEF of $2 \%$ led to stronger patterns than models based on TEF of $1 \%$ and $0 \%$ (i.e. greater importance of $\mathrm{C}_{3}$ sources for all species and stronger seasonal effects). This was expected, given the low $\delta^{13} \mathrm{C}$ of $\mathrm{C}_{3}$ sources. Although the average value of $\delta^{13} \mathrm{C}$ TEF found in the literature is generally <1\%o (e.g. Vander Zanden and Rasmussen 2001: $0.5 \pm 1.2$ \%о ( \pm SD); Post 2002: 0.4 $\pm 1.3 \%$ \% ( $\pm S D$ ); McCutchan et al. 2003: $0.5 \pm 0.13 \%$ ( \pm SE); Caut et al. 2009: $0.8 \pm 0.1 \%$ o $( \pm S E)$ ), those values are based on meta-analyses that consider multiple taxa, environments, and tissues, and $\delta^{13} \mathrm{C}$ TEF varies with all these factors (e.g. Vander Zanden and Rasmussen 2001, McCutchan et al. 2003, Caut et al. 2009). When considering only muscle tissue with no lipid removal, as in the present study, the average $\delta^{13} \mathrm{C}$ TEF is higher: reviews by McCutchan et al. (2003) and Caut et al. (2009) showed that average $\delta^{13} \mathrm{C}$ TEF for non-lipid treated muscle tissue was $1.1 \pm 0.3 \%$ and $1.8 \pm 0.8 \%$ o $( \pm S D)$ respectively. Other studies (not considered in those reviews) also found that a $\delta^{13} \mathrm{C}$ TEF $\geq 2 \%$ is more appropriate for fish muscle (e.g. Barnes et al. 2007, Elsdon et al. 2010) and results from further studies indicate a $\delta^{13} \mathrm{C}$ TEF of 2\%o or higher, despite that fish muscle did not reach equilibrium (Gorokhova \& Hansson 1999, 
Guelinckx et al. 2007, Buchheister \& Latour 2010). Similarly, for crustacean muscle, $\delta^{13} \mathrm{C}$ TEFs larger than 0\% have been reported (Yokoyama et al. 2005: 2.2\%; Suring \& Wing 2009: 0.8\%о). Therefore, results from the mixing models based TEF of $0 \%$ can be considered conservative regarding the contribution of $\mathrm{C}_{3}$ sources, as higher TEF values lead to lower corrected $\delta^{13} \mathrm{C}$ which on turn leads to higher contributions of $\mathrm{C}_{3}$ sources. Models based on TEFs of $1 \%$ and $2 \%$ o can be considered closer to the reality in these systems.

It can be argued that the differences in importance of $\mathrm{C}_{3}$ material between estuaries resulted from spatial differences in $\delta^{13} \mathrm{C}$ values of aquatic producers, which were not measured. Note however that estuarine aquatic producers are often temporarily and spatially variable in $\delta^{13} \mathrm{C}$ at small scales (e.g. Cloern et al. 2002, Guest et al. 2004), so a sample collected at any point in time (or space) is unlikely to be representative of the source available throughout the area over time. This is especially the case for macrotidal systems such as the ones of this study. For example, in similar tropical small creeks, DIC- $\delta^{13} \mathrm{C}$ varies up to $\sim 10 \%$ with tidal level (Bouillon et al. 2007, Maher et al. 2013) and this would lead to similar changes in phytoplankton $\delta^{13} \mathrm{C}$ in less than a day. However, because the six systems considered have similar conditions in terms of size, depth, tidal ranges, turbidity, climate and hydrology, the average carbon stable isotope composition of the different aquatic primary producer categories (e.g. plankton, MPB) is likely to be similar between systems.

Although in the presence of mangroves aquatic primary producers can have lower than expected $\delta^{13} \mathrm{C}$ due to the incorporation of ${ }^{13} \mathrm{C}$-depleted DIC of mangrove origin (Bouillon et al. 2008; e.g. through flushing of crab burrows (Bouillon et al. 2007)), due to their small sizes, large tidal ranges (up to $\sim 4 \mathrm{~m}$ semi-diurnal tides) and relatively shallow depths, the waters in these systems are likely to be well-mixed by tides, and the rapid water exchange is likely to minimize the effect of mangrove-derived ${ }^{13} \mathrm{C}$-depleted DIC over $\delta^{13} \mathrm{C}$ of phytoplankton and other aquatic producers. For example, water residence time in a similar creek in southern Queensland was of only $\sim 1$ tidal cycle despite a narrower tidal range (spring tides of $\sim 2 \mathrm{~m}$ ) (Maher et al. 2013), meaning it is likely that ${ }^{13} \mathrm{C}$-depleted DIC of mangrove origin is rapidly diluted and does not affect $\delta^{13} \mathrm{C}$ of primary producers to the point of affecting $\delta^{13} \mathrm{C}$ of secondary consumers. Although the relatively high salinities found in the dry season could be interpreted as resulting from low mixing of estuarine and marine waters, they are more likely to be a result of high evaporation 
rates over the mangroves, saltmarshes and saltflats (Ridd et al. 1997, Ridd \& Stieglitz 2002). This phenomenon leads to short wet-dry tropical estuaries such as these rapidly becoming hypersaline over the whole length, even if there is effective tidal mixing (Ridd \& Stieglitz 2002). Consequently, the time-averaged stable isotope composition of plankton and other primary producers such as MPB should be similar between systems.

A number of studies found strong variations in plankton/seston $\delta^{13} \mathrm{C}$ in estuaries, which were related to distance to mangroves (e.g. Hemminga et al. 1994, Bouillon et al. 2000). These studies were, however, done in large systems with high freshwater flows that discharge into large bays having, consequently, strong salinity gradients. It is well known that there is a strong positive relationship between salinity and $\delta^{13} C_{D I C}$ (e.g. Fry 2002, Gillikin et al. 2006), so it is likely that the distance to mangroves was not the only cause of those detected gradients in plankton/seston $\delta^{13} \mathrm{C}$. In our study sites, there is no freshwater flow or salinity gradient for most of the year, the creeks are small and open directly into the open ocean, with large tides and waves effectively mixing waters, meaning that at least for the dry season the relationships between estimated mangrove cover and consumer $\delta^{13} \mathrm{C}$ were only due to the presence of mangrove material, and salinity had a limited effect.

If there was a measurable effect of mangrove-derived $\mathrm{DIC}-\delta^{13} \mathrm{C}$ on the time-averaged $\delta^{13} \mathrm{C}$ of aquatic primary producers, this effect would be stronger in the upper reaches of the creeks, and less in the lower reaches because close to the creek mouths the water mixes more effectively. So, $\delta^{13} \mathrm{C}$ of aquatic primary producers in the lower reaches would be more similar between sites and, if $\mathrm{C}_{3}$ sources did not have any contribution to diets, no relationship between estimated mangrove cover and consumer $\delta^{13} \mathrm{C}$ would be found for consumers collected at the lower reaches. This was however not the case (see Fig. 4). On the other hand, due to the lack of freshwater flow, more mangrove material would be accumulated in the creek beds during the dry season, meaning that there would be a higher availability of ${ }^{13} \mathrm{C}$-depleted mangrove carbon at this time, with a stronger effect on $\delta^{13} \mathrm{C}$ of aquatic producers. If the detected differences in $\delta^{13} \mathrm{C}$ were a result of differences in mangrove cover solely due to this indirect effect, then consumers should have lower $\delta^{13} \mathrm{C}$ values in the dry season. While this was true for the banana prawn $P$. merguiensis, the opposite was true for the two fish species, including the planktivore A. vachellii, despite a previous study showing a positive relationship between $D I C-\delta^{13} C$ and planktivorous fish, which was not present for other trophic guilds (Abrantes et al. 2013). 
Note also that MPB and (for Cocoa and Crab Creeks) seagrass, have typically high $\delta^{13} \mathrm{C}$ values, higher than plankton and generally more similar to $C_{4}$ grasses (Clementz \& Koch 2001). So, any possible spatial differences in their $\delta^{13} \mathrm{C}$ between estuaries would not lead to differences in results relating to the relative importance of $\mathrm{C}_{3}$ sources, as these were well separated in $\delta^{13} \mathrm{C}$ when compared to all other potential sources. Nevertheless, the high variability in source $\delta^{13} \mathrm{C}$ used in the mixing model inputs (SD of $\pm 3 \%$ of $\mathrm{MPB}$ and $\pm 2 \%$ o for the remaining sources), coupled with the $1.5 \%$ o uncertainty in TEF values, accounted for the uncertainty in source $\delta^{13} \mathrm{C}$ resulting from the lack of local data on primary producer $\delta^{13} \mathrm{C}$ and therefore the relative contribution of $\mathrm{C}_{3}$ sources presented here can be considered conservative.

Differences in aquatic productivity between systems could have influenced the difference in importance of the different sources to consumers, but no productivity data were collected. Planktonic productivity is however likely to be similar between systems due to similarity in climate, environmental settings such as shading and depth and effective tidal mixing, while benthic productivity could differ between estuaries due to differences in area available for benthic production. However, the shallower estuaries, i.e. the estuaries with the largest intertidal area available for MPB production, were also those with denser and more extensive mangrove forests, so if MPB were of greater importance at these sites, then the contribution of $\mathrm{C}_{3}$ sources would be relatively low, and this was not the case. Although the biomass of benthic algae in mangrove forests is generally low due to shading, these producers can be important in estuaries with greater areas of exposed habitat such as saltmarshes, mudflats and saltflats (Alongi 1988). In Australia's wet-dry tropics, these habitats are generally found at higher elevations and are less frequently inundated than mangroves, so for most of the time MPB are subjected to high temperatures, high salinities and to desiccation, limiting productivity (Blanchard et al. 1996). Hence, differences in plankton and/or MPB productivity can not explain the differences in $\mathrm{C}_{3}$ contribution between estuaries.

It is also possible that other sources such as epiphytes growing on mangrove roots are important but were missing from the models. However, epiphytes are not likely to constitute important source for consumers in these estuaries as the close canopy of mangroves limits light penetration and, consequently, algal biomass and productivity. Also, the high tidal amplitude 
(maximum tidal range of $\sim 4 \mathrm{~m}$ ) means that for most of the time these algae are subjected to desiccation or submerged in the waters generally turbid due to resuspension of soft sediment with the large tides, and both these factors limit the photosynthetic activity and productivity of epiphytic algae. Indeed, previous studies have shown that the abundance and productivity of algae in Australian wet and wet-dry tropical mangrove forests is low and that these areas are zones of net heterotrophy (Alongi et al. 1993, Alongi 1994). Nevertheless, epiphytes in these estuaries would likely have $\delta^{13} \mathrm{C}$ close to plankton (e.g. Boon et al. 1997, Abrantes \& Sheaves 2009, Nyunja et al. 2009, Al-Maslamani et al. 2013) and therefore their inclusion in the models would not have affected the calculated contributions of $\mathrm{C}_{3}$ sources and, therefore, the main conclusions of this study.

It could also be argued that the measured consumer $\delta^{13} \mathrm{C}$ are not a good representation of the average $\delta^{13} \mathrm{C}$ values of the three species sampled, as these were based on only one analysed stable isotope sample per site per reach. However, each sample was composed of up to 15 individuals, and previous studies demonstrated that the analysis of $\sim 5-6$ individuals is sufficient to estimate mean $\delta^{13} \mathrm{C}$ for estuarine prawns (Fry 1981) and fish (Mazumder et al. 2008) within an area. Furthermore, in the calculation of mean $\delta^{13} C$, there is a complete agreement between mean $\delta^{13} \mathrm{C}$ calculated using a number of individuals analysed separately and $\delta^{13} \mathrm{C}$ calculated based on one sample composed by the same number of pooled individuals (Fry 1981). This means that the $\delta^{13} \mathrm{C}$ value of one sample composed by 15 individuals combined is not different to the average $\delta^{13} \mathrm{C}$ calculated based on 15 individuals analysed separately, and therefore the measurement of individuals separately would not provide more information. Note also that the $\delta^{13} \mathrm{C}$ variability of estuarine fish and invertebrates in North Queensland is generally low: of 67 fish and four penaeid species collected at various times from 35 systems in Central and North Queensland, $\delta^{13} \mathrm{C}$ standard deviations ranged from 0.3 to 1.3 ( $25^{\text {th }}-75^{\text {th }}$ percentiles; $n=273$ for fish and $n=56$ for prawns) (authors' unpubl. data). In those studies, the average number of replicates per species was only 3 , meaning that the SDs of $\delta^{13} \mathrm{C}$ from up to 15 individuals is likely to be lower. Note also that SIARSOLO was used in these models, as appropriate for models run based on one data point. 


\section{Seasonal variability in importance of $C_{3}$ sources}

Within each estuary, all three species ultimately relied on similar combinations of sources throughout the length of the estuaries in the wet season, but in the dry season there were often large differences in the ultimate sources of nutrition used by different species and in different reaches. It is possible that this is related to the higher availability of nutrients in the wet season which resulted from the transport of material from upstream and the adjacent catchment with the freshwater flows, stimulating aquatic primary and secondary production (e.g. Hoover et al. 2006, Schlacher et al. 2008). More nutritive and easily assimilated material (i.e. plankton) would then be readily available, supporting abundant invertebrate communities that are prey for fish and other invertebrates. For example in a study in Alligator Creek (located between Cocoa and Sandfly Creeks), a strong seasonality in density of zooplankton community was found, with much higher densities in the wet season than in the dry season (Robertson et al. 1988). Furthermore, different habitats and sites had relatively similar zooplankton communities in the wet season, but these differed in the dry season (Robertson et al. 1988). Since estuarine consumers can switch their diet to feed on temporarily abundant prey (Robertson et al. 1988, Baker \& Sheaves 2009), the different species could feed on this abundant and similar prey assemblage at this time (Robertson et al. 1988), ending up with similar stable isotope composition. In the dry season, however, nutrient and food availability would be lower, and the assemblage of available prey would be less homogeneous throughout the length of the estuaries (Robertson et al. 1988), so the different species would have more diversified diets, feed on different prey assemblages at the different sites and, this would be reflected on differences in $\delta^{13} \mathrm{C}$ between species and reaches. Further studies should be done to investigate this hypothesis.

The argument of increased productivity driven by nutrient input during the wet season may be seen as contradictory to the previously presented hypothesis of lack of significant effect of ${ }^{13} \mathrm{C}$-depleted DIC of mangrove origin over aquatic producers due to the effective flushing of these estuaries, i.e. shouldn't this flux also flush out nutrients from the systems, particularly during the wet season when flows are higher? However, while DIC is likely more effectively flushed from these systems, a significant part of the heavier mangrove detritus probably settles 
and accumulates in the creek beds, where it becomes available to detritivores. The gentle topography of these creeks facilitates retention of this material. There are however no estimates of dissolved organic or inorganic carbon (DIC, DOC) or detritus residency times and exports for these small wet-dry tropical estuaries.

There was also evidence of seasonality in sources of nutrition for the three species. Interestingly, the different species had different patterns of seasonal change in importance of $\mathrm{C}_{3}$ sources: while for $A$. vachellii and $L$. equulus $C_{3}$ sources were more important in the dry season, for $P$. merguiensis $\mathrm{C}_{3}$ sources were generally more important in the wet season. This could be because the different species are part of different food chains. For the two fish species, the lower importance of $\mathrm{C}_{3}$ material during the wet season could have been a result of a more abundant small invertebrate prey community due to the increase in aquatic productivity that resulted from the input of nutrients with the wet season, as explained above. For example, although zooplankton assimilates both phytoplankton and detritus, it feeds selectively, preferring phytoplankton (Cole et al. 2006, Schlacher et al. 2009), so an increased phytoplankton productivity would lead to an increase in importance of aquatic sources and, consequently, in a decrease in relative importance of $\mathrm{C}_{3}$ sources for these species and their predators. For $P$. merguiensis, the greater importance of $\mathrm{C}_{3}$ material in the wet season could result from a greater input of mangrove detritus into the estuaries, as mangrove productivity and litterfall in this region is higher in the wet season (Robertson et al. 1988, Clough 1998). Unlike the two carnivorous fish species, P. merguiensis juveniles are mostly detritivorous (Robertson 1988), so higher availability of mangrove carbon would be more rapidly reflected into an increase in importance of mangrove carbon for the nutrition of this species. This explains the increase in importance of $\mathrm{C}_{3}$ carbon for $P$. merguiensis in the lower and mid reaches, where most mangrove areas are concentrated. Although it is likely that increased mangrove productivity during the wet season is somewhat offset by the reduced residence time due to higher flows, and that the detrital pool contains a higher proportion of algal matter at this time, results suggest that these effects are not sufficient to counteract the higher relative availability of mangrove detritus for detritivorous species during the wet season. 
Therefore, it is possible that wet seasons have two different effects over these food webs, depending on the trophic ecology of the different species: the input of fresh nutrients stimulates aquatic productivity, fuelling algae-based food chains and reducing the relative importance of mangrove carbon for carnivores like $A$. vachellii and L. equulus, while the increase in available mangrove detritus due to increase mangrove productivity leads to an increase in importance of mangrove material for species that rely mostly on detritus-based food chains. This agrees with previous studies (mostly on freshwater systems), that show that detritivorous species are generally more affected by introduction of detrital material into a system than species that ultimately rely mostly on aquatic producers (Marczak et al. 2007, Abrantes \& Sheaves 2010). However, further studies need to be conducted to test for this possibility.

The substantial importance of mangrove material detected in the present study is not in agreement with other studies in tropical regions, as most found limited importance of mangrove carbon to estuarine consumers (e.g. Fry \& Ewel 2003, Layman 2007, Igulu et al. 2013 and references therein). Most studies found mangrove material to be important only for consumers within or in close proximity to the mangrove forests (e.g. Rodelli et al. 1984, Newel et al. 1995, Nyunja et al. 2009, Vaslet et al. 2012), especially in permanently inundated forests (Igulu et al. 2013). However, most of those studies were conducted in systems very different to those of the present study. For example, Heithaus et al. (2011) sampled an open coast area (Shark Bay, Western Australia) with low mangrove productivity (fringing mangroves) and with adjacent seagrass beds, so the potential for mangrove contribution was smaller. Indeed, most available studies were done in areas with adjacent productive seagrass beds (e.g. Loneragan et al. 1997, Nagelkerken \& van der Velde 2004, Heithaus et al. 2011) and/or in much larger systems (e.g. Chanton \& Lewis 2002, Abrantes et al. 2013) where mangrove detritus can be more easily diluted. Only a few recent studies have been conducted in areas where mangrove areas are not in close proximity to other productive coastal habitats such as seagrass beds, which can provide alternative food sources (Giarrisso et al. 2011, Zagars et al. 2013). In those studies, like in the present study, mangrove carbon was found to be important for estuarine fish and invertebrate nutrition (Giarrisso et al. 2011, Zagars et al. 2013). 
Few studies have considered the seasonality in importance of terrestrial material transported from river catchments for tropical estuarine food webs. Those available suggest that this allochthonous source is seasonally important for aquatic consumers. For example, in bays and estuaries of Hong Kong, southern China (Wai et al. 2008, 2011), and Florida, USA (Chanton \& Lewis 2002), in floodplain pools in North Queensland (Abrantes \& Sheaves 2010) and in east African estuaries (Abrantes et al. 2013), there was a significant increase in importance of terrestrial material transported from the catchment during wet season. However, those studies considered systems very different to those from the present study: the North Queensland floodplain pools studied by Abrantes and Sheaves (2010) are small, relatively isolated and typically with a very narrow band of mangrove vegetation, so terrestrial organic matter transported from the catchment is likely to contribute a large proportion to the pool of available sources. The Hong Kong bays (Wai et al. 2008) receive large amounts of water from several hill streams that run through shrubland and forest during the wet summer monsoon, unlike the sites from the present study where rainfall is much lower, even in the wet season, and where the topography is much flatter. The Hong Kong (Wai et al. 2011), Florida (Chanton \& Lewis 2002) and African estuaries (Abrantes et al. 2013), on the other hand, were much larger systems, with much larger catchments and discharges, so great quantities of terrestrial organic matter could be transported from their catchments, making a large contribution to aquatic food webs. Therefore, material from the catchment was likely to contribute to a much larger proportion of the total available carbon than for the systems considered in the present study, where small catchments and little rainfall during most of the year mean that there is limited potential for transport of terrestrial organic matter into the aquatic environment. Thus, unlike in perennial river systems with large catchments, estuarine food webs in small wet-dry tropical estuaries are likely to be less affected by impacts in the terrestrial environment landward of mangrove forests.

\section{Conclusion}


This study shows that mangroves are important contributors to estuarine food webs in small wet-dry tropical estuaries. In systems where extensive mangrove forests are present, mangrove-derived carbon can be the main source of nutrients supporting food webs. This is unlike in large perennial river systems, where aquatic sources such as plankton and benthic algae can have a greater importance (e.g. Chanton \& Lewis 2002), most likely due to differences in ratio of mangrove to intertidal and open water area between these contrasting systems. There were also seasonal differences in sources of nutrition for food webs. Results suggest that this is, at least in part, due to the input of nutrients during the wet season, which stimulated algae-based food chains, reducing the relative importance of mangrove carbon for carnivorous fish like $A$. vachellii and $L$. equulus. At the same time, increases in mangrove productivity during the hot wet season seemed to lead to increases in importance of mangrove material for detritus-based food chains.

\section{Acknowledgements}

We thank the many volunteers, in particular A. Johnson for field assistance. This research was supported by an Australian Government Marine and Tropical Sciences Research Facility (MTSRF) grant to MS and RMC, and by a Winifred Violet Scott Foundation grant to KGA. Work was conducted in accordance with institutional, national and international guidelines concerning the use of animals in research, under the Ethics Permit A1210 from James Cook University. We also thank the anonymous reviewers for their insightful comments. 


\section{References}

Abrantes K, Sheaves M (2008) Incorporation of terrestrial wetland material into aquatic food webs in a tropical estuarine wetland. Estuar Coast Shelf Sci 80:401-412

Abrantes K, Sheaves M (2009a) Food web structure in a near-pristine mangrove area of the Australian Wet Tropics. Estuar Coast Shelf Sci 82: 597-607

Abrantes K, Sheaves M (2009b) Sources of nutrition supporting juvenile penaeid prawns in an Australian dry tropics estuary. Mar Freshwat Res 60:949-959

Abrantes KG, Barnett A, Marwick TR, Bouillon S (2013) Importance of terrestrial subsidies for estuarine food webs in contrasting east African catchments. Ecosphere 4:Art14

Abrantes KG, Sheaves M (2010) Importance of freshwater flow in terrestrial-aquatic energetic connectivity in intermittently connected estuaries of tropical Australia. Mar Biol 157:2071-2086

Al-Maslamani I, Walton M, Kennedy H, Al-Mohannadi M, Le Vay L (2013) Are mangroves in arid environments isolated systems? Life-history and evidence of dietary contribution from inwelling in a mangrove-resident shrimp species. Estuar Coast Shelf Sci 124:56-63

Alongi DM (1988) Bacterial productivity and microbial biomass in tropical mangrove sediments. Microb Ecol 15:59-79

Alongi DM (1994) Zonation and seasonality of benthic primary production and community respiration in tropical mangrove forests. Oecologia 98:320-327

Alongi DM, Christoffersen P, Tirendi F (1993) The influence of forest type on microbial-nutrient relationships in tropical mangrove sediments. J Exp Mar Biol Ecol 171:201-223

Baker R, Sheaves M (2009) Refugees or ravenous predators: detecting predation on new recruits to tropical estuarine nurseries. Wetlands Ecol Manage 17:317-330

Beck MW, Heck KL, Jr, Able KW, Childers DL, Eggleston DB, Gillanders BM, Halpern B, Hays CG, Hoshino K, Minello TJ, Orth RJ, Sheridan PF, Weinstein MP (2001) The identification, conservation, and management of estuarine and marine nurseries for fish and invertebrates. BioScience 51:633-641

Blanchard GF, Guarini J-M, Richard P, Gros P, Mornet F (1996) Quantifying the short-term temperature effect on light-saturated photosynthesis of intertidal microphytobenthos. Mar 
Ecol Prog Ser 134:309-313

Barnes C, Sweeting CJ, Jennings S, Barry JT, Polunin NVC (2007) Effect of temperature and ration size on carbon and nitrogen stable isotope trophic fractionation. Funct Ecol $21: 356-362$

Bond AL, Diamond AW (2011) Recent Bayesian stable-isotope mixing models are highly sensitive to variation in discrimination factors. Ecological Applications 21:1017-1023

Boon PI, Bird FL, Bunn SE (1997) Diet of the intertidal callianassid shrimps Biffarius arenosus and Trypea australiensis (Decapoda:Thalassinidea) in Western Port (southern Australia), determined with multiple stable-isotope analyses. Mar Freshwat Res 48:503-511

Bouillon S, Connolly RM, Gillikin DP (2011) Use of stable isotopes to understand food webs and ecosystem functioning in estuaries. In: Wolanski E, McLusky DS (eds) Treatise on Estuarine and Coastal Science. Waltham: Academic Press

Bouillon S, Connolly RM, Lee SY (2008) Organic matter exchange and cycling in mangrove ecosystems: recent insights from stable isotope studies. J Sea Res 59:44-58

Bouillon S, Middelburg JJ, Dehairs F, Borges AV, Abril G, Flindt MR, Ulomi S, Kristensen E (2007) Importance of intertidal sediment processes and porewater exchange on the water column biogeochemistry in a pristine mangrove creek (Ras Dege, Tanzania). Biogeosciences, 4:311-322

Bouillon S, Moens T, Overmeer I, Koedam N, Dehairs F (2004) Resource utilization patterns of epifauna from mangrove forests with contrasting inputs of local versus imported organic matter. Mar Ecol Prog Ser 278:77-88

Bouillon S, Mohan PC, Sreenivas N, Dehairs F (2000) Sources of suspended organic matter and selective feeding by zooplankton in an estuarine mangrove ecosystem as traced by stable isotopes. Mar Ecol Prog Ser 208:79-92

Boys CA, Kroon FJ, Glasby TM, Wilkinson K (2012) Improved fish and crustacean passage in tidal creeks following floodgate remediation. J Appl Ecol 49:223-233

Buchheister A, Latour RJ (2010) Turnover and fractionation of carbon and nitrogen stable isotopes in tissues of a migratory coastal predator, summer flounder (Paralichthys dentatus). Can J Fish Aquat Sci 67:445-461 
Caut S, Angulo E, Courchamp F (2009) Variation in discrimination factors $\left(\Delta^{15} \mathrm{~N}\right.$ and $\left.\Delta^{13} \mathrm{C}\right)$ : the effect of diet isotopic values and applications for diet reconstruction. J Anim Ecol 46:443453

Cerling TE, Harris JM, MacFadden BJ, Leakey MG, Quade J, Eisenmann V, Ehleringer JR (1997) Global vegetation change through the Miocene/Pliocene boundary. Nature 389:153-158

Chanton J, Lewis FG (2002) Examination of coupling between primary and secondary production in a river-dominated estuary: Apalachicola Bay, Florida, U.S.A. Limnol Oceanogr 47:683-697

Chong VC, Low CB, Ichikawa T (2001) Contribution of mangrove detritus to juvenile prawn nutrition: a dual stable isotope study in a Malaysian mangrove forest. Mar Biol 138:77-86

Clementz MT, Koch PL (2001) Differentiating aquatic mammal habitat and foraging ecology with stable isotopes in tooth enamel. Oecologia 129:461-472

Cloern JE, Canuel EA, Harris D (2002) Stable carbon and nitrogen isotope composition of aquatic and terrestrial plants of the San Francisco Bay estuarine system. Limnol Oceanogr 47:713-729

Clough B (1998) Mangrove forest productivity and biomass accumulation in Hinchinbrook Channel, Australia. Mangroves Salt Marshes 2:191-198

Cole JJ, Carpenter SR, Pace ML, Van de Bogert MC, Kitchell JL, Hodgson JR (2006) Differential support of lake food webs by three types of terrestrial organic carbon. Ecol Lett 9:558-568

Dahlgren CP, Kellison G, Adams AJ, Gillanders BM, Kendall MS, Layman CA, Ley JA, Nagelkerken I, Serafy JE (2006) Marine nurseries and effective juvenile habitats: concepts and applications. Mar Ecol Prog Ser 312:291-295

De'ath G, Fabricius KE (2000) Classification and Regression Trees: a powerful yet simple technique for ecological data analysis. Ecology 81:3178-3192

DeNiro MJ, Epstein S (1978) Influence of diet in the distribution of carbon isotopes in animals. Geochim Cosmochim Acta 42:495-506

Elsdon TS, Ayvazian S, McMahon KW, Thorrold SR (2010) Experimental evaluation of stable 
isotope fractionation in fish muscle and otoliths. Mar Ecol Prog Ser 408:195-205

Erskine WD, Saynor MJ, Erskine L, Evans KG, Moliere DR (2005) A preliminary typology of Australian tropical rivers and implications for fish community ecology. Mar Freshwat Res 56:253-267

Finlayson B, McMahon T (1988) Australia vs the World: a comparative analysis of streamflow characteristics. In: Werner R (ed) Fluvial Geomorphology of Australia, Academic Press, Sydney

France RL (1996) Scope for use of stable carbon isotopes in discerning the incorporation of forest detritus into aquatic foodwebs. Hydrobiologia 325:219-222

Fry B (1981) Natural stable carbon isotope tag traces Texas shrimp migrations. Fish Bull 79:337-345

Fry B (2002) Conservative Mixing of Stable Isotopes across Estuarine Salinity Gradients: A Conceptual Framework for Monitoring Watershed Influences on Downstream Fisheries Production. Estuaries 25:264-271

Fry B, Ewel KC (2003) Using stable isotopes in mangrove fisheries research - a review and outlook. Isotopes in Environmental and Health Studies 39:191-196

Gillikin DP, Lorrain A, Bouillon S, Willenz P, Dehairs F (2006) Stable carbon isotopic composition of Mytilus edulis shells: relation to metabolism, salinity, $\delta^{13} \mathrm{C}-\mathrm{DIC}$ and phytoplankton. Org Geochem 37:1371-1382

Gorokhova E, Hansson S (1999) An experimental study on variations in stable carbon and nitrogen fractionation during growth of Mysis mixta and Neomysis integer. Can J Fish Aquat Sci 56:2203-2210

Guelinckx J, Maes J, van den Driessche P, Geysen B, Dehairs F, Ollevier F (2007) Changes in $\delta^{13} \mathrm{C}$ and $\delta^{15} \mathrm{~N}$ in different tissues of juvenile sand goby Pomatoschistus minutus: a laboratory diet-switch experiment. Mar Ecol Prog Ser 341:205-215

Guest M, Connolly RM, Loneragan N (2004) Within and among-site variability in $\delta^{13} \mathrm{C}$ and $\delta^{15} \mathrm{~N}$ for three estuarine producers, Sporobolus virginicus, Zostera capricorni, and epiphytes of $Z$. capricorni. Aquat Bot 79:87-94

Haywood MDE, Staples DJ (1993) Field estimates of growth and mortality of juvenile banana 
prawns (Penaeus merguiensis). Mar Biol 116:407-416

Heithaus ER, Heithaus PA, Heithaus MR, Burkholder D, Layman CA (2011) Trophic dynamics in a relatively pristine subtropical fringing mangrove community. Mar Ecol Prog Ser 428:49-61

Hemminga MA, Slim FJ, Kazungu J, Ganssen GM, Nieuwenhuize J, Kruyt NM (1994) Carbon outwelling from a mangrove forest with adjacent seagrass beds and coral reefs (Gazy Bay, Kenya). Mar Ecol Prog Ser 106:291-301

Hoover RS, Hoover D, Miller M, Landry MR, DeCarlo EH, Mackenzie FT (2006) Zooplankton response to storm runoff in a tropical estuary: bottom-up and top-down controls. Mar Ecol Prog Ser 318:187-201

Igulu M, Nagelkerken I, van der Velde G, Mgaya Y (2013) Mangrove fish production is largely fuelled by external food sources: a stable isotope analysis of fishes at the individual, species, and community levels from across the globe. Ecosystems 16:1336-1352

Layman CA (2007) What can stable isotope ratio reveal about mangroves as fish habitat? Bull Mar Sci 80:513-527

Jennerjahn TC, Ittekkot V (2002) Relevance of mangroves for the production and deposition of organic matter along tropical continental margins. Naturwissenschaften 89:23-30

Kristensen E, Bouillon S, Dittmar T, Marchand C (2008) Organic carbon dynamics in mangrove ecosystems: A review. Aquat Bot 89:201-219

Lancaster J, Waldron S (2001) Stable isotope values of lotic invertebrates: sources of variation, experimental design, and statistical interpretation. Limnol Oceanogr 46:723-730

Lin H-J, Kao W-Y, Wang Y-T (2007) Analyses of stomach contents and stable isotopes reveal food sources of estuarine detritivorous fish in tropical/subtropical Taiwan. Estuar Coast Shelf Sci 73:527-537

Loneragan NR, Bunn SE, Kellaway DM (1997) Are mangroves and seagrasses sources of organic carbon for penaeid prawns in a tropical Australian estuary? A multiple stableisotope study. Mar Biol 130:289-300

Lotze HK, Lenihan HS, Bourque BJ, Bradbury RH, Cooke RG, Kay MC, Kidwell SM, Kirby MX, Peterson $\mathrm{CH}$, Jackson JBC (2006) Depletion, degradation, and recovery potential of 
estuaries and coastal seas. Science 312:1806-1809

Maher DT, Santos IR, Golsby-Smith L, Gleeson J, Eyre BD (2013) Groundwater-derived dissolved inorganic and organic carbon exports from a mangrove tidal creek: The missing mangrove carbon sink? Limnol Oceanogr 58:475-488

Mazumder D, Williams RJ, Reir D, Saintilan N, Szymczak R (2008) Variability of stable isotope ratios of glassfish (Ambassis jacksoniensis) from mangrove/saltmarsh environments in southeast Australia and emplications for choosing sample size. Environ Bioindic 3:114123

Marczak LB, Thompson RM, Richardson JS (2007) Meta analysis: trophic level, habitat, and productivity shape the food web effects of resource subsidies. Ecology 88:140-148

Mavuti KM, Nyunja JA, Wakwabi EO (2007) Trophic ecology of some common juvenile fish species in Mtwapa Creek, Kenya. West Indian Ocean J Mar Sci 3:179-188

McCutchan JH, Lewis Jr WM, Kendall C, McGrath CC (2003) Variation in trophic shift for stable isotope ratios of carbon, nitrogen and sulfur. Oikos 102:378-390

Nagelkerken I, van der Velde G (2004) Are Caribbean mangroves important feeding grounds for juvenile reef fish from adjacent seagrass beds? Mar Ecol Prog Ser 274:143-151

Newell RIE, Marshall N, Sasekumar A, Chong VC (1995) Relative importance of benthic microalgae, phytoplankton, and mangroves as sources of nutrition for penaeid prawns and other coastal invertebrates from Malaysia. Mar Biol 123:595-606

Nyunja J, Ntiba M, Onyari J, Mavuti K, Soetaert K, Bouillon S (2009) Carbon sources supporting a diverse fish community in a tropical coastal ecosystem (Gazi Bay, Kenya). Estuar Coast Shelf Sci 83:333-341

Parnell AC, Inger R, Bearhop S, Jackson AL (2010) Source Partitioning Using Stable Isotopes: Coping with Too Much Variation. PLOS ONE 5:e9672

Peel MC, Finlayson BL, McMahon TA (2007) Updated world map of the Köppen-Geiger climate classification. Hydrol Earth Syst Sci Discuss 4:439-473

Peterson BJ, Howarth RW, Garritt RH (1986) Sulfur and carbon isotopes as tracers of saltmarsh organic matter flow, Ecology 67:865-874

Polis GA, Anderson WB, Holt RD (1997) Towards an integration of landscape and food web 
ecology: the dynamics of spatially subsidized food webs. Annu Rev Ecol Syst 28:289316

Post DM (2002) Using stable isotopes to estimate trophic position: models, methods and assumptions. Ecology 83:703-718

Post DM, Layman CA, Arrington DA, Takimoto G, Quattrochi J, Montanã CG (2007) Getting to the fat of the matter: models, methods and assumptions for dealing with lipids in stable isotope analyses. Oecologia 152:179-189

Ridd P, Sam R, Hollins S, Brunskill G (1997) Water, salt and nutrient fluxes of tropical tidal salt flats. Mangroves Salt Marshes 1:229-238

Ridd PV, Stieglitz T (2002) Dry season salinity changes in arid estuaries fringed by mangroves and saltflats. Estuar Coast Shelf Sci 54:1039-1049

Robertson Al (1988) Abundance, diet and predators of juvenile banana prawns, Penaeus merguiensis, in a tropical mangrove estuary. Aust J Mar Freshw Res 39:467-478

Robertson AI, Blaber SJM (1992) Plankton, epibenthos and fish communities. In: Robertson Al, Alongi DM (eds) Tropical Mangrove Ecossystems, Book 41. American Geophysical Union, Washington DC

Robertson Al, Dixon P, Daniel PA (1988) Zooplankton dynamics in mangrove and other nearshore habitats in tropical Australia. Mar Ecol Prog Ser 43:139-150

Robertson Al, Duke NC (1990) Recruitment, growth and residence time of fishes in a tropical Australian mangrove system. Estuar Coast Shelf Sci 31:723-743

Rodelli MR, Gearing JN, Gearing PJ, Marshall N, Sasekumar A (1984) Stable isotope ratio as a tracer of mangrove carbon in Malaysian ecosystems. Oecologia 61:326-333

Schlacher TA, Connolly RM, Skillington AJ, Gaston TF (2009) Can export of organic matter from estuaries support zooplankton in nearshore, marine plumes? Aquat Ecol 43:383-393

Schlacher TA, Skillington AJ, Connolly RM, Robinson W, Gaston TF (2008) Coupling between marine plankton and freshwater flow in the plumes off a small estuary. Int Rev Hydrobiol 93:641-658

Sheaves M, Brookes J, Coles R, Freckelton M, Groves P, Johnston R, Winberg P (2014) Repair and revitalisation of Australia's tropical estuaries and coastal wetlands: opportunities and 
constraints for the reinstatement of lost function and productivity. Mar Pol 47:23-38

Sheaves M, Johnston R (2009) Ecological drivers of spatial variability among fish fauna of 21 tropical Australian estuaries. Mar Ecol Prog Ser 385:245-260

Sheaves M, Johnston R, Connolly R (2010) Temporal dynamics of fish assemblages of natural and artificial tropical estuaries. Mar Ecol Prog Ser 410:143-157

Sheaves M (1996). Do Spatial Differences in the Abundance of Two Serranid Fishes in Estuaries of Tropical Australia Reflect Long-Term Salinity Patterns? Mar Ecol Prog Ser 137: $39-49$

Sheaves M, Johnston R (2010) Implications of spatial variability of fish assemblages for monitoring of Australia's tropical estuaries. Aquat Conserv: Mar Freshwat Ecosyst 20:348-356

Sheaves M, Johnston R, Connolly RM (2012) Fish assemblages as indicators of estuary ecosystem health. Wetlands Ecol Manage 20:477-490

Sheaves M, Johnston R, Johnson A, Baker R, Connolly R (2013) Nursery function drives temporal patterns in fish assemblage structure in four tropical estuaries. Estuar Coast

Sheaves M, Molony B (2000) Short-circuit in the mangrove food chain. Mar Ecol Prog Ser 199:97-109

Suring E, Wing SR (2009) Isotopic turnover rate and fractionation in multiple tissues of red rock lobster (Jasus edwardsii) and blue cod (Parapercis colias): Consequences for ecological studies. J Exp Mar Biol Ecol 370:56-63

Vander Zanden MJ, Rasmussen JB (2001) Variation in $\delta^{15} \mathrm{~N}$ and $\delta^{13} \mathrm{C}$ trophic fractionation: implication for aquatic food web studies. Limnol Oceanogr 46:2061-2066

Vance DJ, Haywood MDE, Heales DS, Kenyon RA, Loneragan NR, Pendrey RC (1996) How far do prawns and fish move into mangroves? Distribution of juvenile banana prawns Penaeus merguiensis and fish in a tropical mangrove forest in northern Australia. Mar Ecol Prog Ser 131:115-124

Vaslet A, Phillips DL, France C, Feller IC, Baldwin CC (2012) The relative importance of mangroves and seagrass beds as feeding areas for resident and transient fishes among different mangrove habitats in Florida and Belize: Evidence from dietary and stable- 
isotope analyses. J Exp Mar Biol Ecol 434-435:81-93

Wai T-C, Leung KMY, Sin SYT, Cornish A, Dudgeon D, Williamsa GA (2011) Spatial, seasonal, and ontogenetic variations in the significance of detrital pathways and terrestrial carbon for a benthic shark, Chiloscyllium plagiosum (Hemiscylliidae), in a tropical estuary. Limnol Oceanogr 56:1035-1053

Wai T-C, Ng JS, Leung KM, Dudgeon D, Williams GA (2008) The source and fate of organic matter and the significance of detrital pathways in a tropical coastal ecosystem. Limnol Oceanogr 53:1479-1492

Weidel BC, Carpenter SR, Kitchell JF, Vander Zanden MJ (2011) Rates and components of carbon turnover in fish muscle: insights from bioenergetics models and a whole-lake ${ }^{13} \mathrm{C}$ addition. Can J Fish Aquat Sci 68:387-399

Wilson JP, Sheaves M (2001) Short-term temporal variations in taxonomic composition and trophic structure of a tropical estuarine fish assemblage. Mar Biol 139:787-796

Yokoyama H, Tamaki A, Harada K, Shimoda K, Koyama K, Ishihi Y (2005) Variability of diettissue isotopic fractionation in estuarine macrobenthos. Mar Ecol Prog Ser 296:115-128 
Table 1. Turbidity, salinity, intertidal area relative of total estuary surface area (ranked from 1 to 5 ) and percentage cover of mangroves, terrestrial $\mathrm{C}_{3}$ forests, total $\mathrm{C}_{3}$ cover (including mangroves and terrestrial forests), $\mathrm{C}_{4}$ vegetation (including saltmarsh, pasture land and sugarcane plantations), savannah vegetation $\left(\mathrm{C}_{3} / \mathrm{C}_{4}\right.$ mix $)$ and saltflats in each estuary. Percentage cover calculated for the area within $1 \mathrm{~km}$ from the river margins, up to the upper extend of tidal reach. For turbidity and salinity, data for the wet and dry seasons are presented, and values indicate measurements made at the lower (close to estuary mouth) followed by the upper reaches (close to the limit of saltwater intrusion).

\begin{tabular}{|c|c|c|c|c|c|c|c|c|c|c|c|}
\hline \multirow[b]{2}{*}{ Estuary } & \multicolumn{2}{|c|}{ Salinity } & \multicolumn{2}{|c|}{ Turbidity (NTU) } & \multirow{2}{*}{$\begin{array}{c}\text { Intertidal } \\
\text { (rank) }\end{array}$} & \multirow{2}{*}{$\begin{array}{l}\% \text { Cover } \\
\text { Mangrove }\left(\mathrm{C}_{3}\right)\end{array}$} & \multirow[b]{2}{*}{ Terr $\mathbf{C}_{3}$ forest } & \multirow[b]{2}{*}{ Tot $\mathrm{C}_{3}$} & \multirow[b]{2}{*}{$\mathrm{C}_{4}$} & \multirow[b]{2}{*}{ Savanna } & \multirow[b]{2}{*}{ Saltflat } \\
\hline & Wet & Dry & Wet & Dry & & & & & & & \\
\hline Cocoa Ck & $34 / 35$ & $39 / 47$ & $78 / 37$ & $20 / 17$ & 1 & 18.9 & 0.0 & 18.9 & 5.9 & 20.5 & 54.7 \\
\hline Crab Ck & $33 / 32$ & $40 / 43$ & $121 / 28$ & $12 / 18$ & 2 & 27.6 & 0.0 & 27.6 & 36.6 & 0.6 & 35.2 \\
\hline Doughboy Ck & $26 / 30$ & $46 / 45$ & $72 / 43$ & $15 / 21$ & 3 & 49.6 & 32.0 & 81.6 & 15.6 & 2.3 & $<1$ \\
\hline Hell Hole Ck & $16 / 18$ & $42 / 37$ & $25 / 18$ & $8 / 28$ & 4 & 41.5 & 14.1 & 55.5 & $<1$ & 43.9 & $<1$ \\
\hline Mud Ck & $28 / 32$ & $43 / 46$ & $26 / 42$ & $12 / 19$ & 5 & 47.4 & 20.6 & 68.0 & 19.9 & 4.5 & 7.6 \\
\hline Sandfly Ck & - & $40 / 45$ & - & $30 / 56$ & 1 & 20.0 & 0.0 & 20.0 & 43.1 & 24.8 & 12.0 \\
\hline
\end{tabular}


Table 2. Size range and carbon stable isotope composition (mean \pm SD) of each species in the wet (March 2008) and dry season (November 2008). $n$ is number of samples for the lower (L), mid (M) and upper (U) reaches, followed (in brackets) by the number of individuals pooled in each sample. NC = Not collected.

\begin{tabular}{|c|c|c|c|c|c|c|}
\hline & \multicolumn{3}{|l|}{ Wet Season } & \multicolumn{3}{|l|}{ Dry Season } \\
\hline & Size (mm) & $\delta^{13} \mathrm{C}$ & $n$ & Size (mm) & $\delta^{13} \mathrm{C}$ & $n$ \\
\hline \multicolumn{7}{|l|}{ P. merguiensis } \\
\hline Cocoa Ck & $35-45$ & $-18.3 \pm 1.0$ & L:1(15); M:1(15); U:1(15) & $30-50$ & $-17.7 \pm 1.1$ & L:1(15); M:1(3)U:1(15) \\
\hline Crab Ck & $35-45$ & $-20.0 \pm 1.1$ & L:1(16); M:1(15); U:1(14) & $35-45$ & $-18.3 \pm 0.7$ & L:1(13); M:1(3); U:1(4) \\
\hline Doughboy Ck & $35-45$ & $-23.0 \pm 0.6$ & L:1(15); M:1(15); U:1(15) & $30-50$ & $-21.6 \pm 0.5$ & L:NC; M:2(4-8); U:1(5) \\
\hline Hell Hole & $35-45$ & $-22.4 \pm 0.1$ & L:1(10); M:NC; U:1(7) & $35-45$ & $-21.6 \pm 3.1$ & L:1(5); M:1; 7); U:1(15) \\
\hline Mud Ck & $35-45$ & $-23.7 \pm 0.3$ & L:1(15); M:1(15); U:1(15) & $25-40$ & $-22.2 \pm 1.9$ & L:1(5); M:1(13); U:1; 7) \\
\hline Sandfly Ck & - & - & - & $30-50$ & $-18.2 \pm 0.7$ & L:1(15); M:1(15); U:1(13) \\
\hline \multicolumn{7}{|l|}{ A. vachellii } \\
\hline Cocoa Ck & $35-45$ & $-18.2 \pm 0.4$ & L:NC; M:2(5-15); U:NC & $35-60$ & $-18.0 \pm 0.8$ & L:1(7); M:NC; U:1(2) \\
\hline Crab Ck & $35-45$ & $-20.0 \pm 0.3$ & L:1(15); M:1(15); U:1(15) & $40-45$ & $-21.4 \pm 1.9$ & L:1(1); M:1(1) \\
\hline Doughboy Ck & $35-45$ & $-21.8 \pm 0.5$ & L:1(15); M:1(15); U:1(15) & - & - & - \\
\hline Hell Hole & $35-45$ & $-21.9 \pm 0.4$ & L:1(15); M:1(15); U:1(15) & $40-50$ & $-21.7 \pm 0.4$ & L:NC; M:3(3-8); U:NC \\
\hline Mud Ck & $35-45$ & $-22.5 \pm 0.6$ & L:1(15); M:1(15); U:1(15) & $35-50$ & $-24.4 \pm 0.3$ & L:3(5); M:NC; U:NC \\
\hline
\end{tabular}


Sandfly Ck

L. equulus

Cocoa Ck

Crab Ck

Doughboy Ck

Hell Hole

Mud Ck

30-45

$-17.7 \pm 0.8 \quad \mathrm{~L}: 3(6-7) ; \mathrm{M}: 1(7)$

$30-40$

$-19.8 \pm 0.3 \quad$ L:NC; M:1(2); U:1(8)

30-40 $\quad-23.0 \pm 0.6 \quad$ L:1(7); M:1(15); U:1(15)

25-40 $\quad-22.5 \pm 0.5 \quad$ L:1(5); M:1(7); U:1(7)

30-45

$-23.5 \pm 1.5 \quad \mathrm{~L}: 1(14) ; \mathrm{M}: 1(7) \mathrm{U}: 1(11)$
$35-40$

$55-75$

$35-50$

35-50

45-55

45-70

$15-50$
$-21.3 \pm 0.5 \quad$ L:1(15); M:1(15); U:1(9)

Sandfly Ck 
Table 3. Results from stepwise multiple linear regression analysis testing the effects of mangrove cover and total $\mathrm{C}_{3}$ cover (in $\%$ ) on the modal contribution of $\mathrm{C}_{3}$ sources ( $\mathrm{C}_{3-\text { cont; }}$; based on Bayesian mixing models) for Penaeus merguiensis, Ambassis vachellii and Leiognathus equulus in the wet and dry seasons, while considering TEFs of $0 \%, 1 \%$ and $2 \%$. $\mathrm{R}^{2}$ and $\mathrm{p}$-values are presented for the variables included in the models.

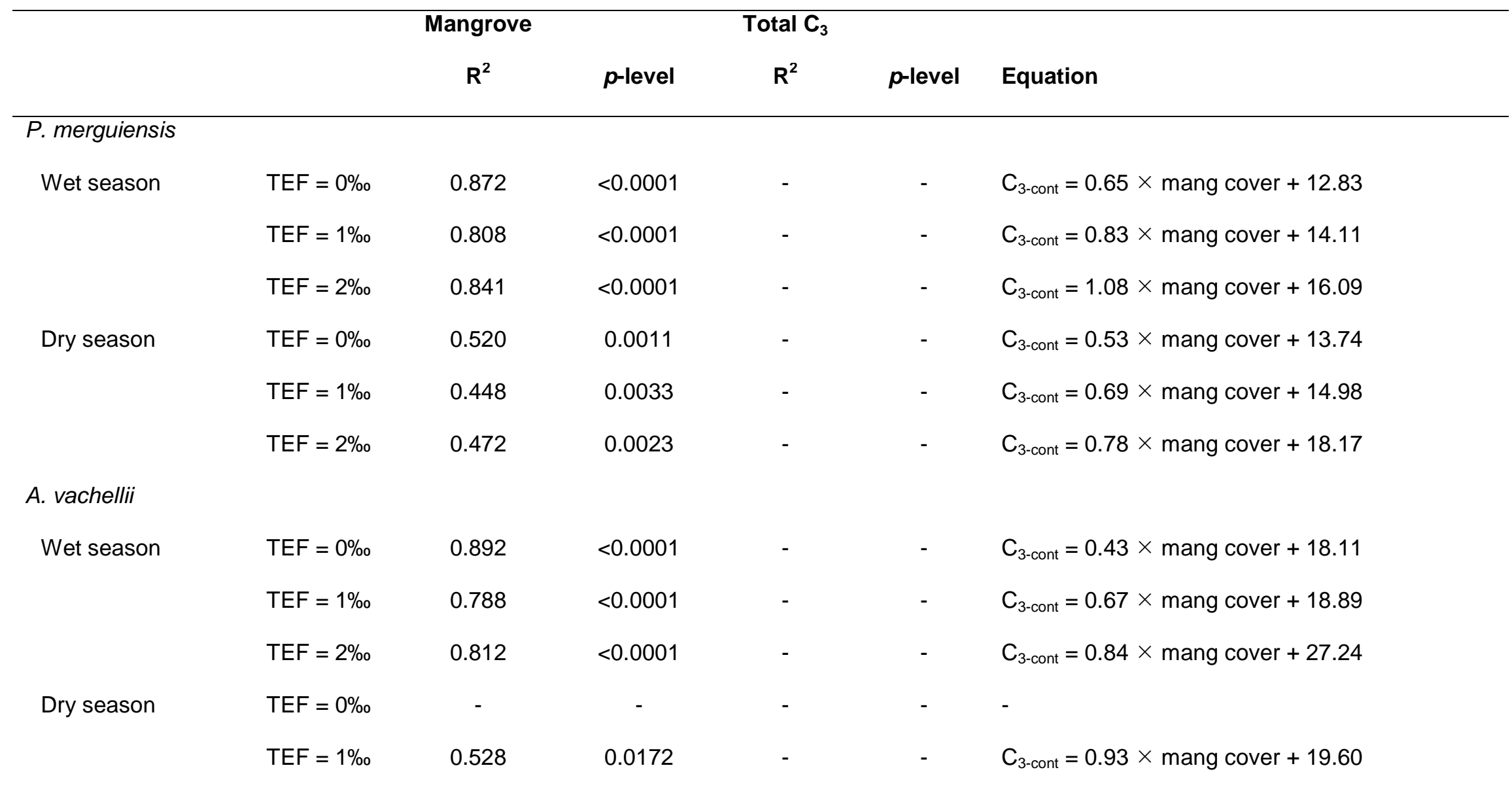


TEF $=2 \% \circ \quad 0.484 \quad 0.0376$

L. equulus

\begin{tabular}{lllll} 
Wet season & TEF $=0 \%$ & 0.794 & 0.0001 & - \\
TEF $=1 \%$ & 0.680 & 0.0010 & - \\
Dry season & TEF $=2 \%$ & 0.871 & $<0.0001$ & - \\
TEF $=0 \%$ & 0.667 & 0.0007 & - \\
TEF $=1 \%$ & 0.573 & 0.0044 & - \\
TEF $=2 \%$ & 0.762 & $<0.0001$ & - \\
\hline
\end{tabular}

$C_{3-\text { cont }}=0.92 \times$ mang cover +33.05

- $\quad C_{3 \text {-cont }}=0.71 \times$ mang cover +10.55

- $\quad C_{3-\text { cont }}=0.97 \times$ mang cover +12.51

- $\quad C_{3 \text {-cont }}=1.16 \times$ mang cover +17.65

- $\quad C_{3-\text { cont }}=0.97 \times$ mang cover +12.97

- $\quad C_{3-\text { cont }}=1.03 \times$ mang cover +22.01

- $\quad C_{3-\text { cont }}=1.11 \times$ mang cover +29.43 


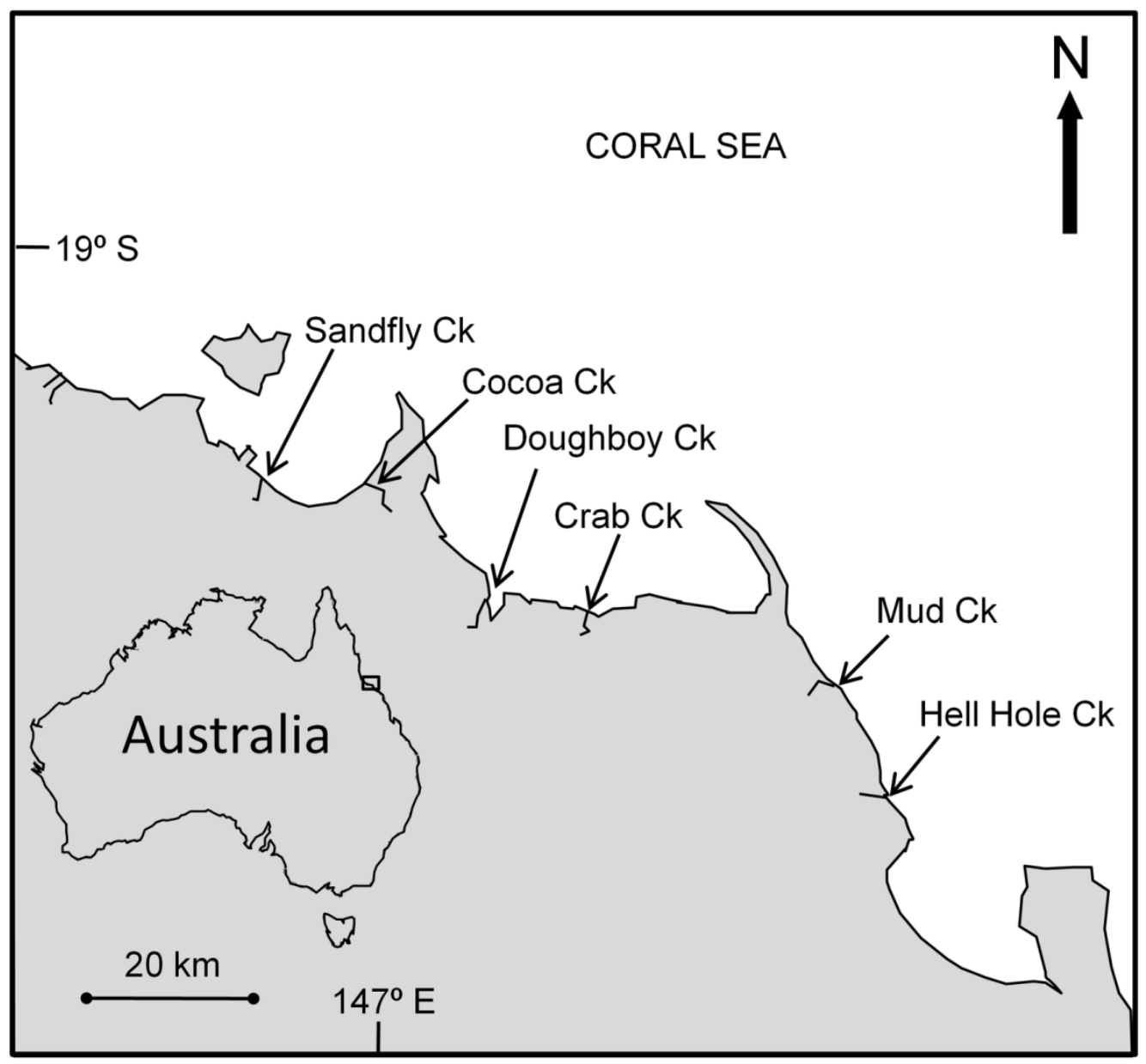

Fig. 1. Map showing the study sites in North Queensland, Australia. 


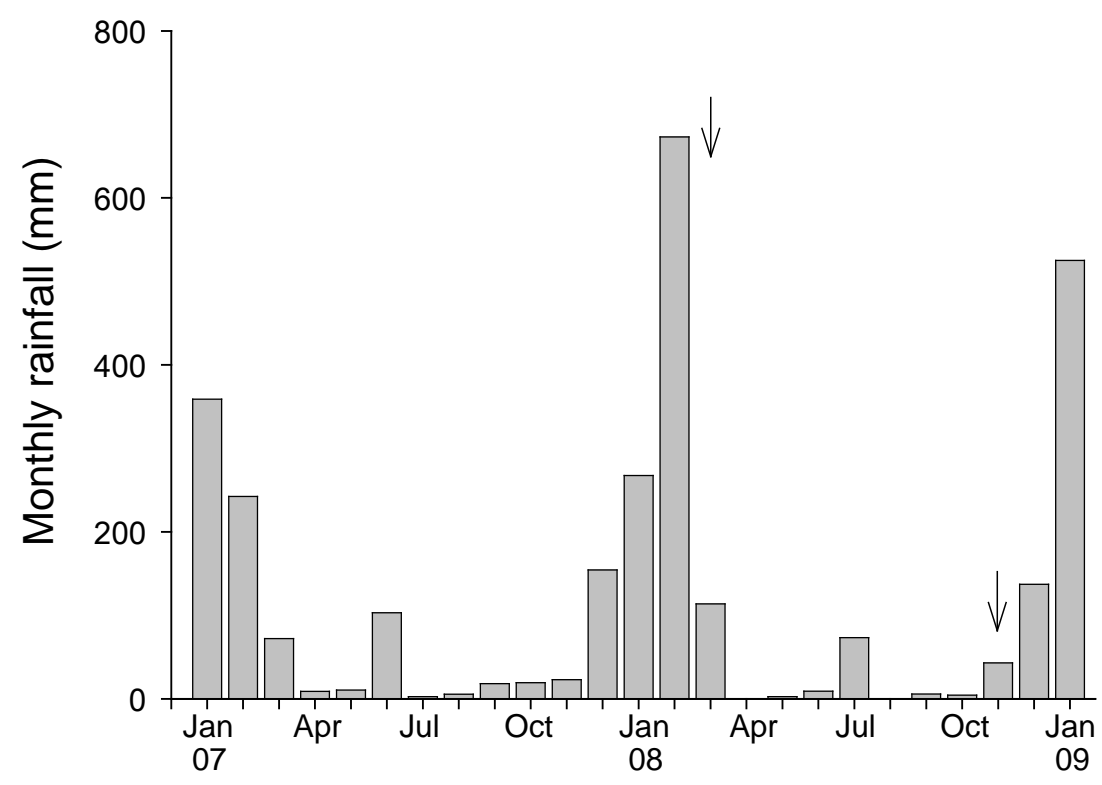

Fig. 2. Monthly rainfall recorded at Alva Beach Meteorological Station (7 km north of Mud Ck) between January 2007 and January 2009 (Bureau of Meteorology 2013). The two sampling times of March (wet season) and November 2008 (dry season) are indicated with arrows. 


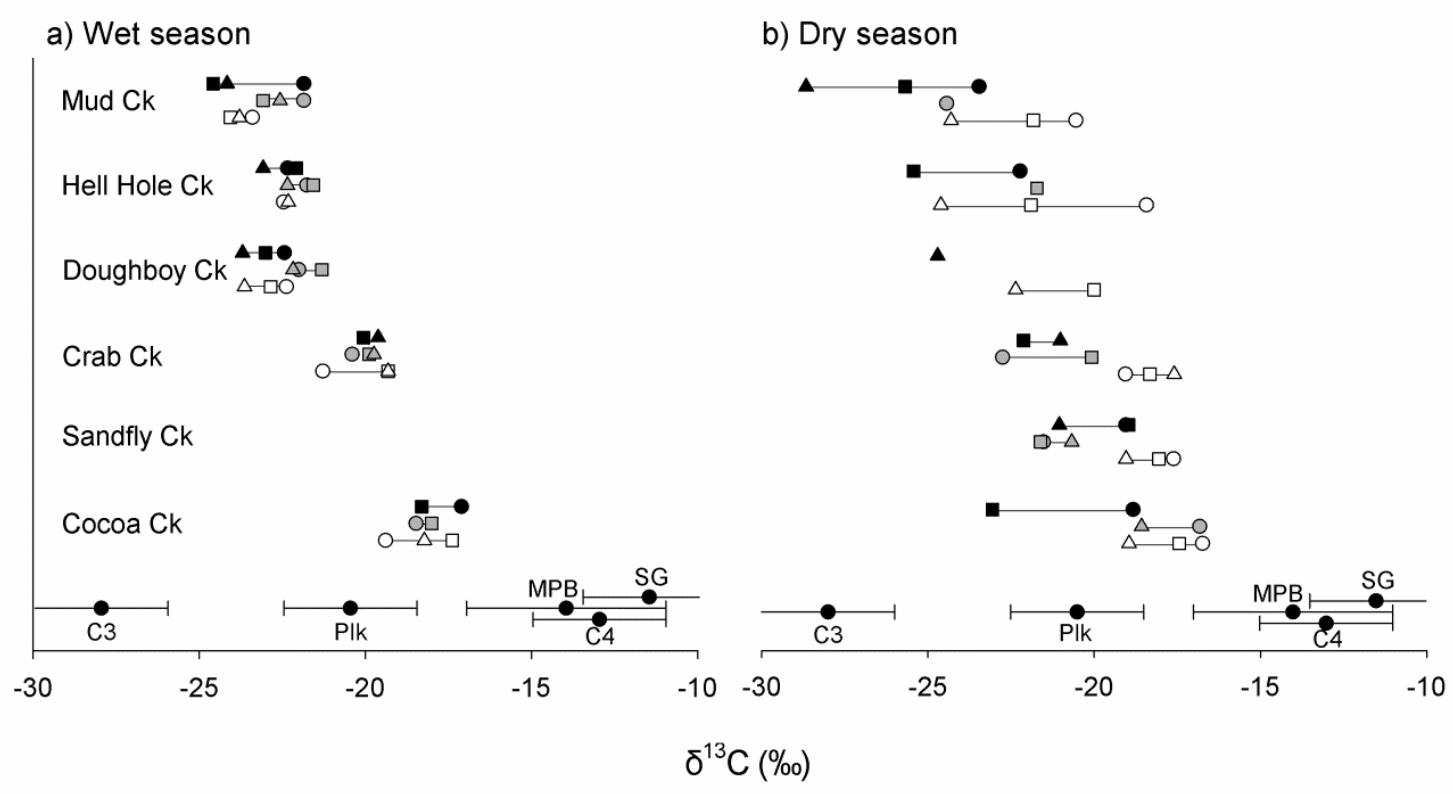

Fig. 3. Carbon stable isotope composition of consumers. The $\delta^{13} \mathrm{C}$ values of possible sources (mean $\pm \mathrm{SD}$; as used in the Bayesian mixing models), is also indicated below the plots (see text for details). $\mathrm{C} 3=\mathrm{C}_{3}$ sources; $\mathrm{C} 4=\mathrm{C}_{4}$ sources, $\mathrm{MPB}=$ microphytobenthos; Plk = plankton; SG = seagrass (only present in Cocoa and Crab Creeks). 


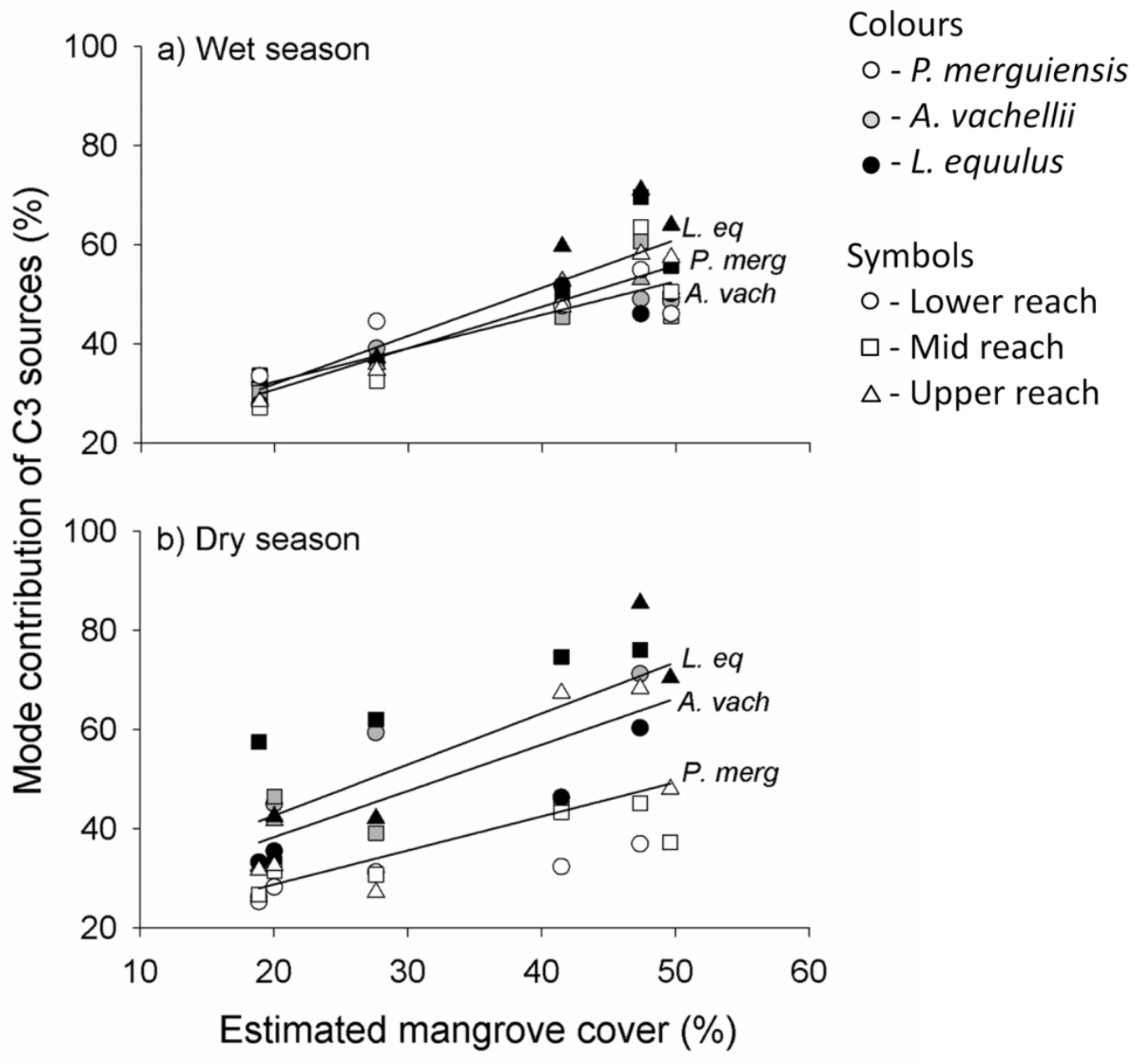

Fig. 4. Relationships between the estimated mangrove cover in the vicinity of each estuary and the mode contribution of $\mathrm{C}_{3}$ sources (based on Bayesian mixing models, while considering a TEF of $1 \%$ ) to each species. Sites are represented by the estimated mangrove cover: Cocoa Ck: 18.9\%; Sandfly Ck: 20.0\%; Crab Ck: 27.6\%; Hell Hole Ck: 41.5\%; Mud Ck: 47.4\%; Doughboy Ck: 49.6\%. All relationships were significant $(p<0.05)$. See Table 3 for relationship details. 
a) $\mathrm{TEF}=0 \% \mathrm{o}$

Estuary: Cocoa, Crab, Sandfly | Doughboy, Hell Hole, Mud

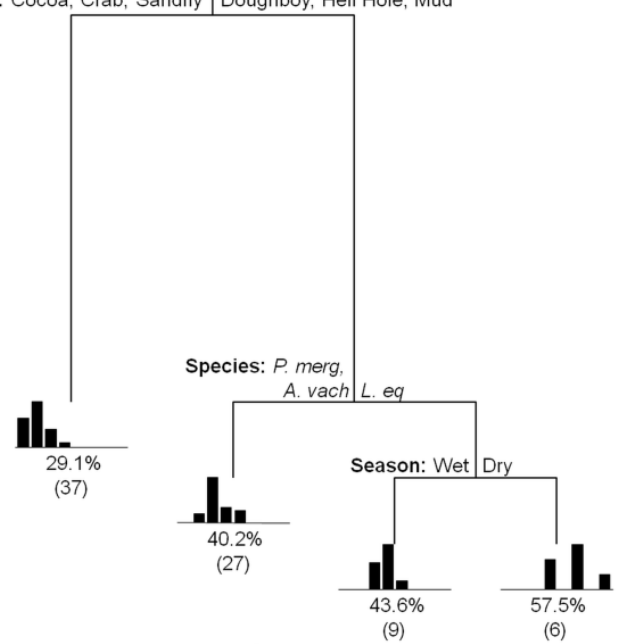

b) $\mathrm{TEF}=1 \%$ o

$$
\mathrm{R}^{2}=63 \%
$$

Estuary: Cocoa, Crab, Sandfly |Doughboy, Hell Hole, Mud

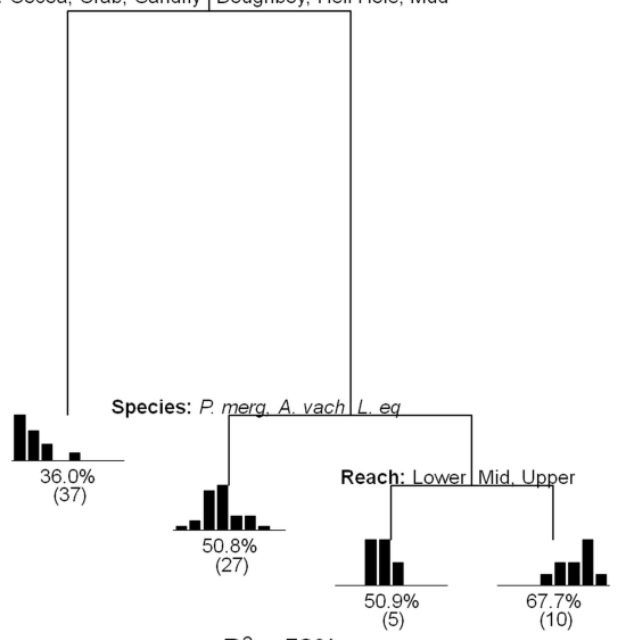

$$
\mathrm{R}^{2}=59 \%
$$

c) $\mathrm{TEF}=2 \%$

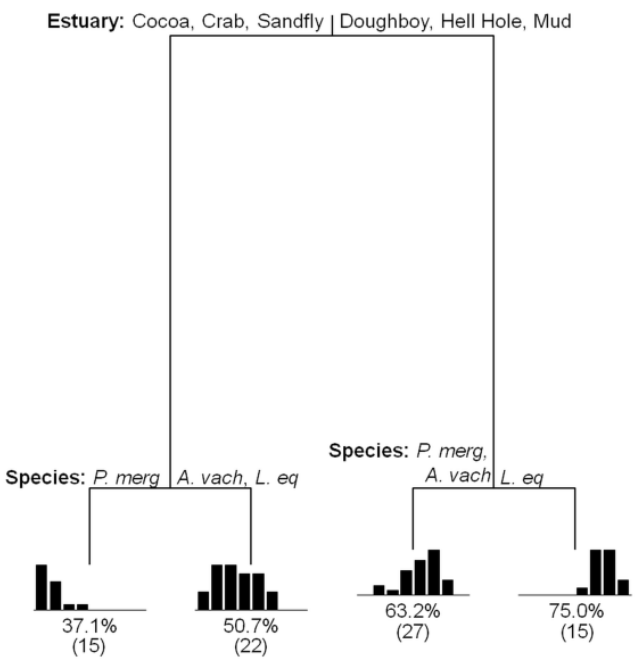

$$
\mathrm{R}^{2}=65 \%
$$

44 
Fig. 5. Classification and regression tree explaining the contribution of $\mathrm{C}_{3}$ sources to consumer diets based on estuary of collection, reach, season and species. Input data were the mode contribution of $\mathrm{C}_{3}$ sources, based on Bayesian mixing model results, while considering a TEF of a) $0 \%$, b) $1 \%$ and c) $2 \%$. Histograms of distribution of mode contribution of $\mathrm{C}_{3}$ sources are presented below the terminal nodes, and mean contribution (in \%) and sample size (in brackets) for each group are also indicated. 
a) $\mathrm{TEF}=0 \%$

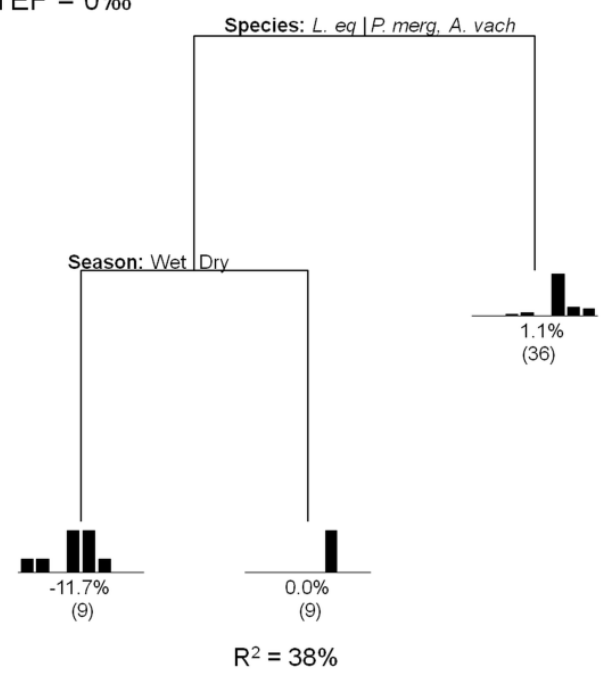

b) $\mathrm{TEF}=1 \%$

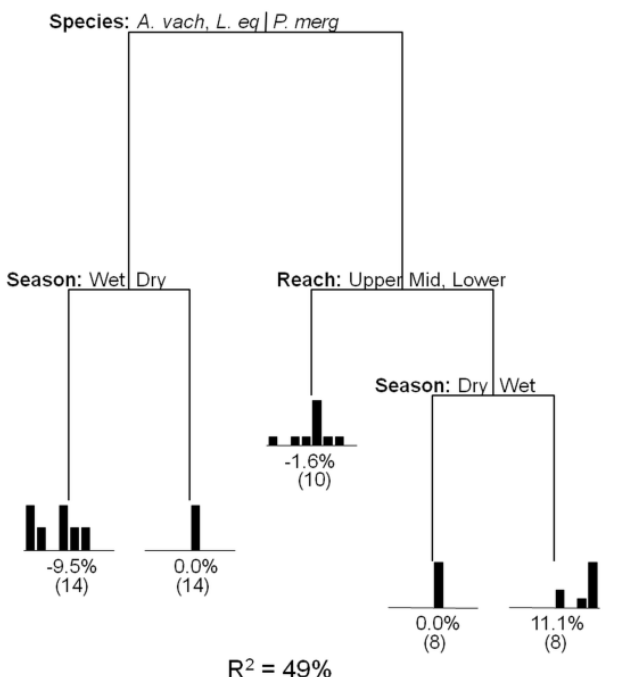

c) $\mathrm{TEF}=2 \%$

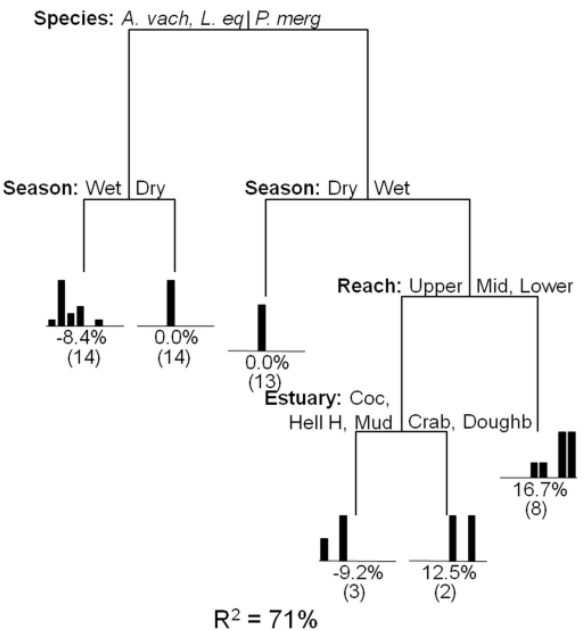


Fig. 6. Classification and regression trees explaining the seasonal changes in importance of $\mathrm{C}_{3}$ sources for the three consumer species when Bayesian models were computed using a TEF of a) $0 \%$, b) $1 \%$ and c) $2 \%$. Explanatory variables were species, estuary, reach (lower, mid and upper) and season. Models calculated based on the differences in mode contribution of $\mathrm{C}_{3}$ sources (based on Bayesian mixing model results) between the dry and wet season using data from all cases when a species was collected in the same estuary and same reach at both seasons. Graphs below each leaf are the histograms of distribution of the values of shifts in contribution of $\mathrm{C}_{3}$ sources (in \%). Mean shift (in \%) and sample size (in brackets) for each group are indicated below each graph. 
Electronic Supplement 1. Solutions of the Bayesian mixing models for the contributions of the different sources to $P$. merguiensis, $A$. vachellii and $L$. equulus diets in the lower (L), mid (M) and upper $(U)$ reach of each estuary, for the wet and dry seasons, while considering a TEF of $1 \%$. Symbols indicate the mode of contribution of the different sources, and bars are the $95 \%$ Bayesian credibility intervals. White circles $=C_{3}$ sources; black circles $=C_{4}$ sources; white squares = benthic microalgae; black squares = planktonic sources; white triangles = seagrass (only present in Cocoa and Crab Creeks). 
Dry season

Cocoa Ck

P. merg

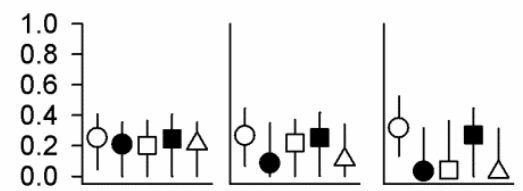

A. vach

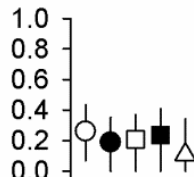

L. eq

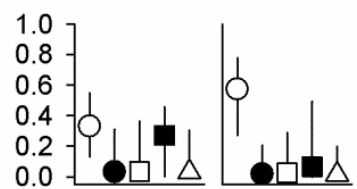

\section{Crab Ck}

P. merg

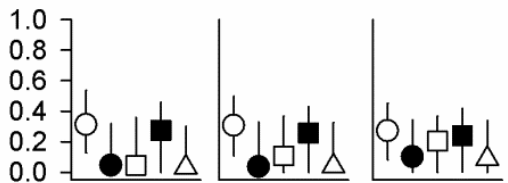

A. vach
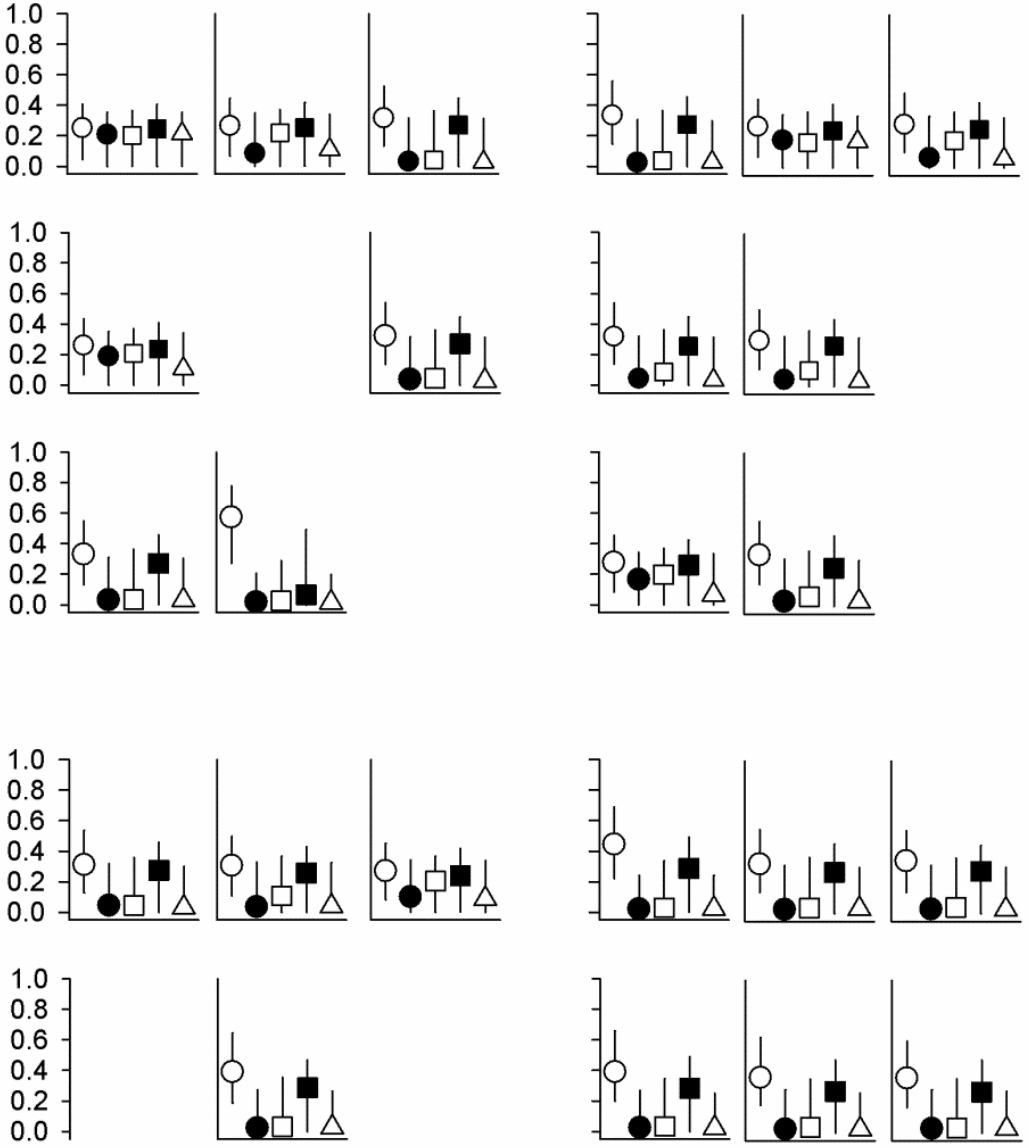

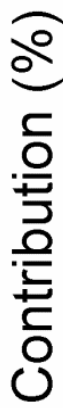

L. eq
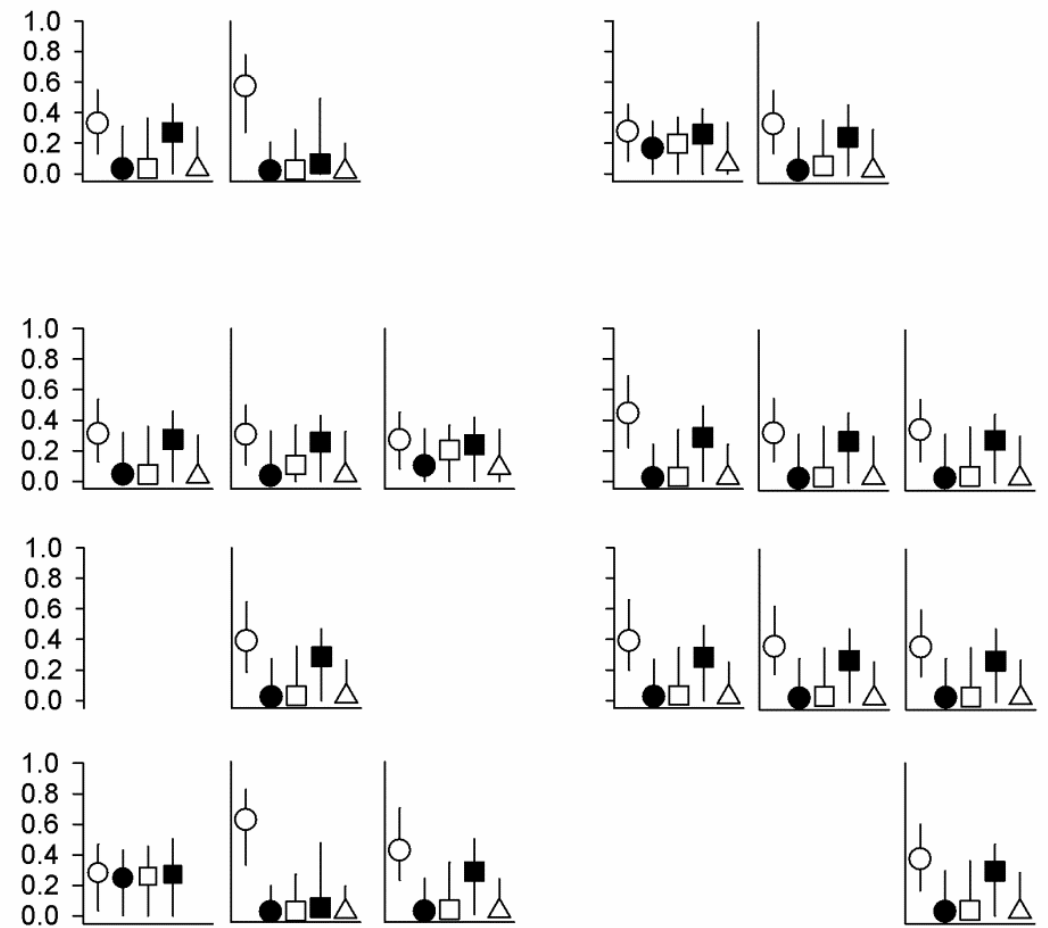

Sandfly Ck

P. merg

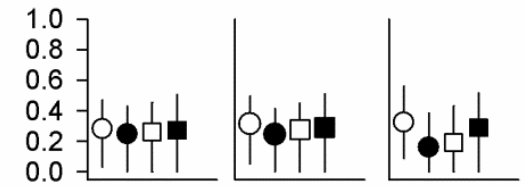

A. vach

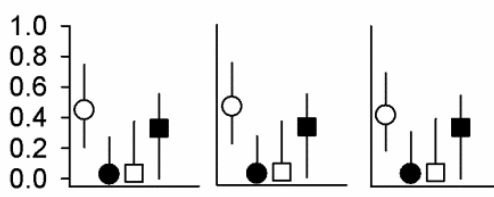

L. eq

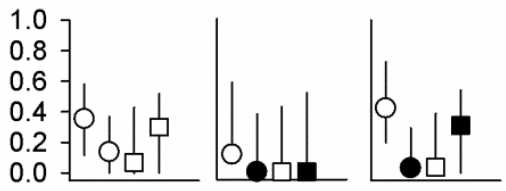




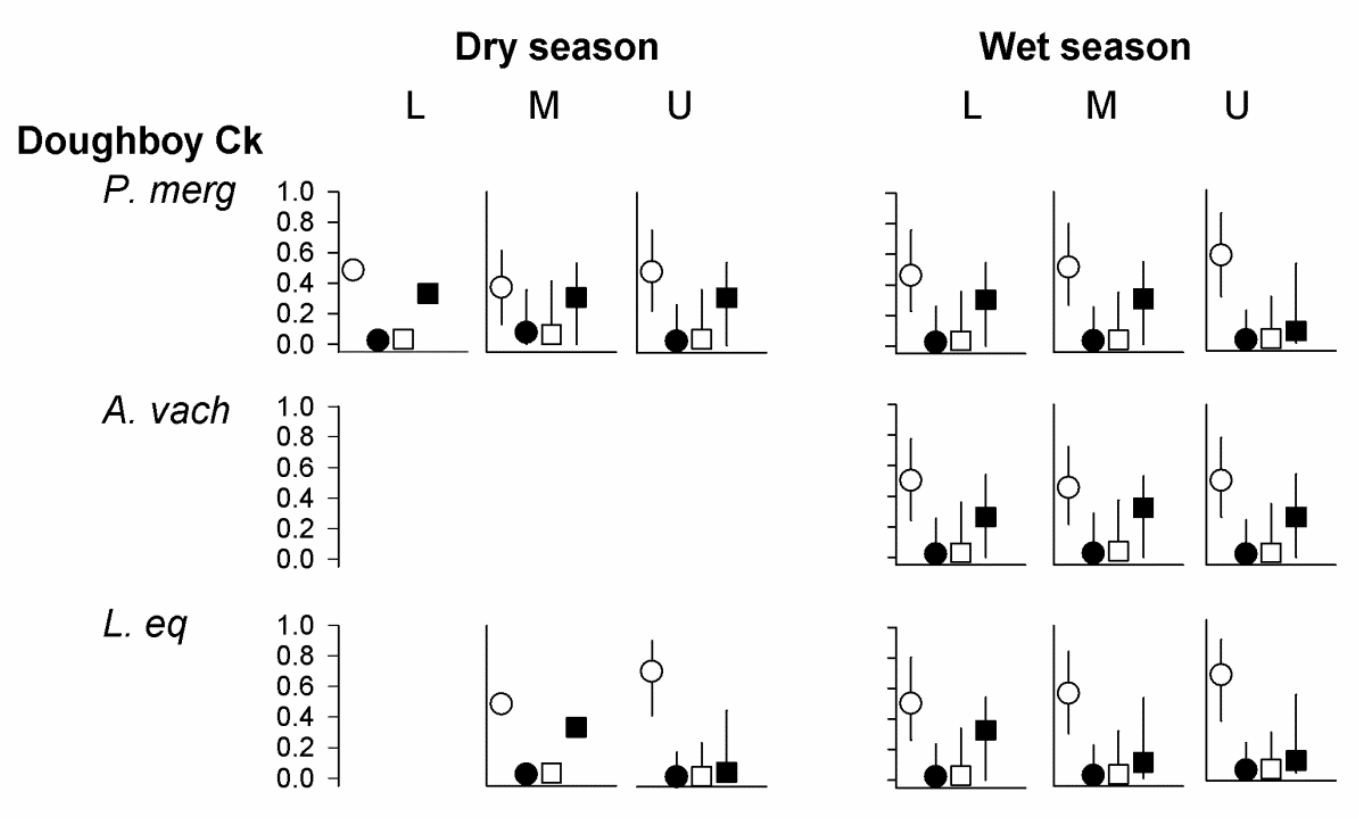

Hell Hole Ck

P. merg
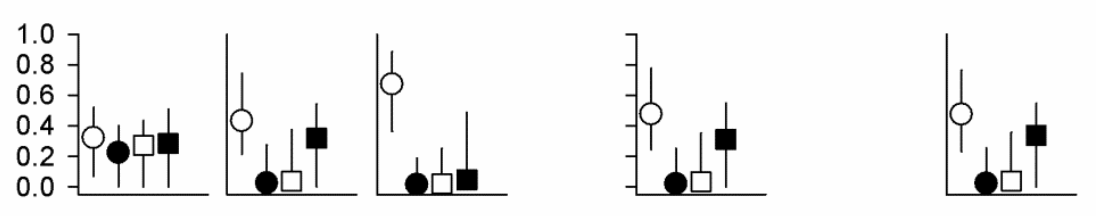

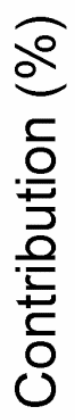

A. vach
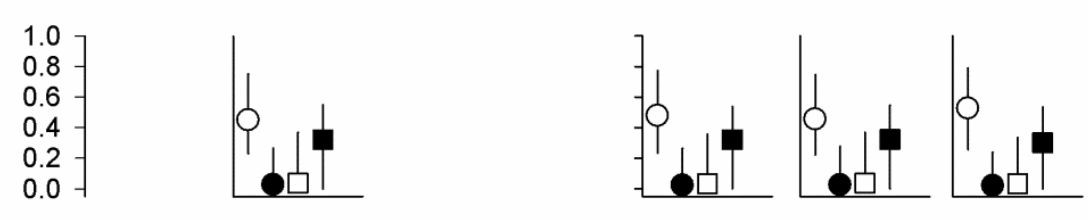

L. eq
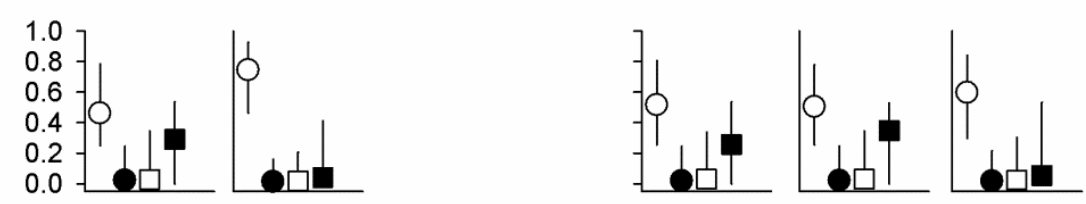

Mud Ck

P. merg
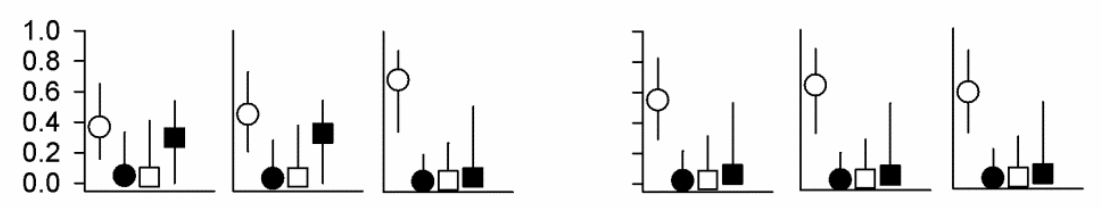

A. vach
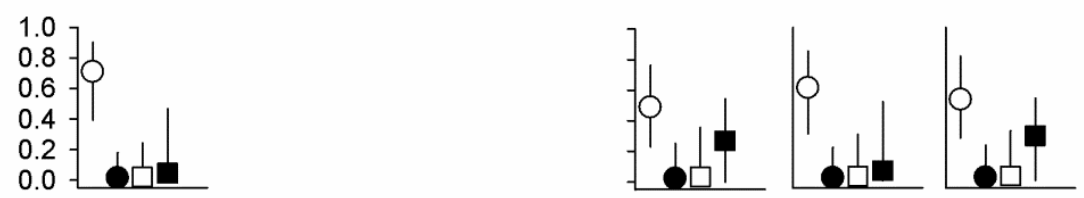

L. eq
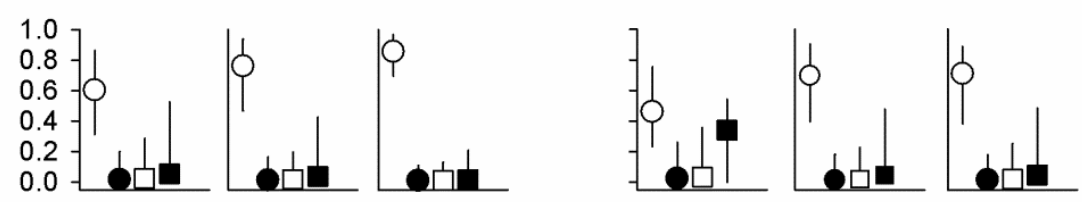
Electronic Supplement 2. Bayesian isotope mixing model (SIAR) solutions (mode of percentage contribution followed by $95 \%$ credibility intervals) of the different sources to $P$. merguiensis, $A$. vachellii and $L$. equulus diets in the lower $(L)$, mid (M) and upper (U) reach of each estuary, for the wet and dry seasons. Models were computed while considering TEFs of $0 \%$, $1 \%$ and $2 \%$.

\begin{tabular}{|c|c|c|c|c|c|c|c|}
\hline Season & Species & Site & Reach & Source & TF $=0 \%$ & TEF = 1\%o & TEF = 2\%o \\
\hline \multirow[t]{25}{*}{ Wet season } & P. merguiensis & Cocoa Ck & Lower & $\mathrm{C}_{3}$ & $28(9-48)$ & $34(15-56)$ & $43(21-66)$ \\
\hline & & & & $\mathrm{C}_{4}$ & $4(0-34)$ & $3(0-30)$ & $3(0-26)$ \\
\hline & & & & MPB & $15(0-37)$ & $4(0-37)$ & $3(0-35)$ \\
\hline & & & & Plk & $25(0-42)$ & $27(0-45)$ & $28(0-49)$ \\
\hline & & & & SG & $6(0-33)$ & $3(0-30)$ & $2(0-25)$ \\
\hline & & & Mid & $\mathrm{C}_{3}$ & $23(3-37)$ & $27(7-45)$ & $32(12-52)$ \\
\hline & & & & $\mathrm{C}_{4}$ & $22(0-37)$ & $18(0-35)$ & $4(0-32)$ \\
\hline & & & & MPB & $22(0-37)$ & $17(0-37)$ & $4(0-36)$ \\
\hline & & & & Plk & $23(0-39)$ & $24(0-41)$ & $26(0-45)$ \\
\hline & & & & SG & $22(0-37)$ & $17(0-34)$ & $5(0-31)$ \\
\hline & & & Upper & $\mathrm{C}_{3}$ & $25(5-41)$ & $28(10-49)$ & $33(16-58)$ \\
\hline & & & & $\mathrm{C}_{4}$ & $23(0-35)$ & $7(0-34)$ & $3(0-30)$ \\
\hline & & & & MPB & $20(0-37)$ & $18(0-36)$ & $4(0-36)$ \\
\hline & & & & Plk & $25(0-40)$ & $25(0-43)$ & $26(0-46)$ \\
\hline & & & & SG & $20(0-35)$ & $6(0-33)$ & $3(0-29)$ \\
\hline & & Crab Ck & Lower & $\mathrm{C}_{3}$ & $34(16-59)$ & $45(22-69)$ & $57(28-78)$ \\
\hline & & & & $\mathrm{C}_{4}$ & $3(0-30)$ & $2(0-24)$ & $2(0-21)$ \\
\hline & & & & MPB & $3(0-36)$ & $3(0-34)$ & $2(0-28)$ \\
\hline & & & & Plk & $28(0-46)$ & $29(0-49)$ & $6(0-50)$ \\
\hline & & & & SG & $3(0-29)$ & $2(0-24)$ & $2(0-19)$ \\
\hline & & & Mid & $\mathrm{C}_{3}$ & $28(9-47)$ & $33(14-55)$ & $42(19-65)$ \\
\hline & & & & $\mathrm{C}_{4}$ & $7(0-34)$ & $3(0-32)$ & $2(0-26)$ \\
\hline & & & & MPB & $18(0-37)$ & $4(0-37)$ & $3(0-35)$ \\
\hline & & & & Plk & $26(0-42)$ & $27(0-46)$ & $27(0-49)$ \\
\hline & & & & SG & $10(0-34)$ & $3(0-30)$ & $2(0-26)$ \\
\hline
\end{tabular}




\begin{tabular}{|c|c|c|c|c|c|}
\hline & \multirow[t]{5}{*}{ Upper } & $\mathrm{C}_{3}$ & $29(9-47)$ & $35(14-54)$ & $39(19-66)$ \\
\hline & & $\mathrm{C}_{4}$ & $12(0-34)$ & $3(0-31)$ & $2(0-27)$ \\
\hline & & MPB & $18(0-37)$ & $4(0-36)$ & $3(0-35)$ \\
\hline & & Plk & $25(0-42)$ & $28(0-45)$ & $29(0-49)$ \\
\hline & & SG & $6(0-33)$ & $3(0-30)$ & $2(0-25)$ \\
\hline \multirow[t]{12}{*}{ Doughboy Ck } & \multirow[t]{4}{*}{ Lower } & $\mathrm{C}_{3}$ & $39(17-67)$ & $46(23-76)$ & $58(32-86)$ \\
\hline & & $\mathrm{C}_{4}$ & $3(0-32)$ & $2(0-26)$ & $2(0-21)$ \\
\hline & & MPB & $4(0-39)$ & $3(0-36)$ & $2(0-29)$ \\
\hline & & Plk & $32(0-53)$ & $30(0-55)$ & $6(0-51)$ \\
\hline & \multirow[t]{4}{*}{ Mid } & $\mathrm{C}_{3}$ & $41(19-70)$ & $51(26-79)$ & $68(35-88)$ \\
\hline & & $\mathrm{C}_{4}$ & $3(0-30)$ & $2(0-24)$ & $2(0-20)$ \\
\hline & & MPB & $4(0-39)$ & $3(0-34)$ & $2(0-26)$ \\
\hline & & Plk & $33(0-55)$ & $30(0-54)$ & $5(0-50)$ \\
\hline & \multirow[t]{4}{*}{ Upper } & $\mathrm{C}_{3}$ & $47(23-75)$ & $57(30-85)$ & $73(40-91)$ \\
\hline & & $\mathrm{C}_{4}$ & $3(0-27)$ & $2(0-21)$ & $2(0-18)$ \\
\hline & & MPB & $4(0-36)$ & $3(0-30)$ & $2(0-24)$ \\
\hline & & Plk & $31(0-54)$ & $8(0-52)$ & $4(0-47)$ \\
\hline \multirow[t]{8}{*}{ Hell Hole } & \multirow[t]{4}{*}{ Lower } & $\mathrm{C}_{3}$ & $40(17-67)$ & $48(25-78)$ & $62(31-86)$ \\
\hline & & $\mathrm{C}_{4}$ & $5(0-32)$ & $2(0-25)$ & $2(0-20)$ \\
\hline & & MPB & $5(0-39)$ & $3(0-35)$ & $2(0-29)$ \\
\hline & & Plk & $32(0-55)$ & $31(0-55)$ & $5(0-52)$ \\
\hline & \multirow[t]{4}{*}{ Upper } & $\mathrm{C}_{3}$ & $38(16-66)$ & $47(23-76)$ & $58(31-85)$ \\
\hline & & $\mathrm{C}_{4}$ & $4(0-32)$ & $2(0-26)$ & $2(0-21)$ \\
\hline & & MPB & $4(0-40)$ & $4(0-36)$ & $2(0-30)$ \\
\hline & & Plk & $32(0-54)$ & $34(0-55)$ & $5(0-53)$ \\
\hline \multirow[t]{6}{*}{ Mud Ck } & \multirow[t]{4}{*}{ Lower } & $\mathrm{C}_{3}$ & $44(21-73)$ & $55(29-82)$ & $70(39-90)$ \\
\hline & & $\mathrm{C}_{4}$ & $2(0-28)$ & $2(0-22)$ & $2(0-18)$ \\
\hline & & MPB & $4(0-37)$ & $3(0-31)$ & $2(0-24)$ \\
\hline & & Plk & $31(0-54)$ & $6(0-53)$ & $5(0-48)$ \\
\hline & \multirow[t]{2}{*}{ Mid } & $\mathrm{C}_{3}$ & $48(24-79)$ & $64(32-87)$ & $73(45-92)$ \\
\hline & & $\mathrm{C}_{4}$ & $2(0-25)$ & $2(0-20)$ & $2(0-17)$ \\
\hline
\end{tabular}




\begin{tabular}{|c|c|c|c|c|c|c|}
\hline & & & MPB & $3(0-35)$ & $3(0-28)$ & $2(0-21)$ \\
\hline & & & Plk & $30(0-54)$ & $5(0-52)$ & $4(0-44)$ \\
\hline & & Upper & $\mathrm{C}_{3}$ & $48(23-77)$ & $58(32-86)$ & $70(42-92)$ \\
\hline & & & $\mathrm{C}_{4}$ & $3(0-26)$ & $2(0-21)$ & $2(0-18)$ \\
\hline & & & MPB & $3(0-36)$ & $3(0-29)$ & $2(0-22)$ \\
\hline & & & Plk & $35(0-54)$ & $5(0-52)$ & $4(0-45)$ \\
\hline \multirow[t]{25}{*}{ A. vachellii } & Cocoa Ck & Lower & $\mathrm{C}_{3}$ & $26(5-42)$ & $32(14-54)$ & $42(21-67)$ \\
\hline & & & $\mathrm{C}_{4}$ & $17(0-35)$ & $4(0-32)$ & $2(0-26)$ \\
\hline & & & MPB & $22(0-37)$ & $9(0-36)$ & $3(0-34)$ \\
\hline & & & Plk & $25(0-41)$ & $25(0-45)$ & $28(0-49)$ \\
\hline & & & SG & $20(0-34)$ & $3(0-31)$ & $2(0-25)$ \\
\hline & & Mid & $\mathrm{C}_{3}$ & $25(4-40)$ & $30(11-50)$ & $39(19-62)$ \\
\hline & & & $\mathrm{C}_{4}$ & $22(0-36)$ & $5(0-33)$ & $3(0-27)$ \\
\hline & & & MPB & $23(0-38)$ & $11(0-37)$ & $3(0-35)$ \\
\hline & & & Plk & $24(0-40)$ & $27(0-44)$ & $26(0-48)$ \\
\hline & & & SG & $22(0-36)$ & $3(0-32)$ & $2(0-26)$ \\
\hline & Crab Ck & Lower & $\mathrm{C}_{3}$ & $32(13-53)$ & $39(20-66)$ & $57(28-79)$ \\
\hline & & & $\mathrm{C}_{4}$ & $4(0-33)$ & $3(0-27)$ & $2(0-20)$ \\
\hline & & & MPB & $4(0-36)$ & $3(0-35)$ & $2(0-28)$ \\
\hline & & & Plk & $26(0-45)$ & $28(0-49)$ & $5(0-49)$ \\
\hline & & & SG & $3(0-31)$ & $2(0-25)$ & $2(0-19)$ \\
\hline & & Mid & $\mathrm{C}_{3}$ & $30(11-50)$ & $36(18-63)$ & $49(27-76)$ \\
\hline & & & $\mathrm{C}_{4}$ & $4(0-33)$ & $3(0-28)$ & $2(0-22)$ \\
\hline & & & MPB & $12(0-36)$ & $4(0-35)$ & $2(0-30)$ \\
\hline & & & Plk & $26(0-43)$ & $27(0-48)$ & $5(0-49)$ \\
\hline & & & SG & $4(0-32)$ & $2(0-26)$ & $2(0-21)$ \\
\hline & & Upper & $\mathrm{C}_{3}$ & $30(11-49)$ & $36(17-60)$ & $50(26-75)$ \\
\hline & & & $\mathrm{C}_{4}$ & $4(0-33)$ & $3(0-28)$ & $2(0-22)$ \\
\hline & & & MPB & $6(0-36)$ & $3(0-35)$ & $3(0-31)$ \\
\hline & & & Plk & $26(0-43)$ & $27(0-48)$ & $5(0-49)$ \\
\hline & & & SG & $4(0-32)$ & $3(0-27)$ & $2(0-20)$ \\
\hline
\end{tabular}




\begin{tabular}{|c|c|c|c|c|c|}
\hline \multirow[t]{12}{*}{ Doughboy Ck } & \multirow[t]{4}{*}{ Lower } & $\mathrm{C}_{3}$ & $38(15-64)$ & $49(24-77)$ & $63(36-88)$ \\
\hline & & $\mathrm{C}_{4}$ & $6(0-34)$ & $2(0-25)$ & $2(0-19)$ \\
\hline & & MPB & $5(0-40)$ & $3(0-36)$ & $2(0-26)$ \\
\hline & & Plk & $33(0-53)$ & $33(0-54)$ & $5(0-50)$ \\
\hline & \multirow[t]{4}{*}{ Mid } & $\mathrm{C}_{3}$ & $37(13-60)$ & $46(22-72)$ & $60(32-85)$ \\
\hline & & $\mathrm{C}_{4}$ & $7(0-36)$ & $3(0-29)$ & $2(0-21)$ \\
\hline & & MPB & $8(0-42)$ & $4(0-37)$ & $3(0-29)$ \\
\hline & & Plk & $30(0-52)$ & $32(0-53)$ & $5(0-52)$ \\
\hline & \multirow[t]{4}{*}{ Upper } & $\mathrm{C}_{3}$ & $40(16-67)$ & $50(26-78)$ & $69(38-89)$ \\
\hline & & $\mathrm{C}_{4}$ & $3(0-33)$ & $2(0-24)$ & $2(0-18)$ \\
\hline & & MPB & $4(0-41)$ & $3(0-35)$ & $2(0-24)$ \\
\hline & & Plk & $31(0-54)$ & $26(0-54)$ & $5(0-48)$ \\
\hline \multirow[t]{12}{*}{ Hell Hole } & \multirow[t]{4}{*}{ Lower } & $\mathrm{C}_{3}$ & $36(14-63)$ & $48(23-77)$ & $63(35-88)$ \\
\hline & & $\mathrm{C}_{4}$ & $7(0-35)$ & $2(0-26)$ & $2(0-19)$ \\
\hline & & MPB & $4(0-41)$ & $3(0-36)$ & $2(0-27)$ \\
\hline & & Plk & $32(0-53)$ & $32(0-54)$ & $4(0-50)$ \\
\hline & \multirow[t]{4}{*}{ Mid } & $\mathrm{C}_{3}$ & $36(14-62)$ & $45(22-75)$ & $63(32-86)$ \\
\hline & & $\mathrm{C}_{4}$ & $6(0-35)$ & $3(0-28)$ & $2(0-20)$ \\
\hline & & MPB & $5(0-41)$ & $4(0-37)$ & $2(0-28)$ \\
\hline & & Plk & $31(0-53)$ & $32(0-54)$ & $5(0-51)$ \\
\hline & \multirow[t]{4}{*}{ Upper } & $\mathrm{C}_{3}$ & $39(17-67)$ & $53(26-79)$ & $68(39-90)$ \\
\hline & & $\mathrm{C}_{4}$ & $3(0-32)$ & $2(0-24)$ & $2(0-18)$ \\
\hline & & MPB & $5(0-40)$ & $3(0-34)$ & $2(0-25)$ \\
\hline & & Plk & $33(0-54)$ & $30(0-53)$ & $4(0-47)$ \\
\hline \multirow[t]{7}{*}{ Mud Ck } & \multirow[t]{4}{*}{ Lower } & $\mathrm{C}_{3}$ & $37(15-64)$ & $49(23-76)$ & $65(35-88)$ \\
\hline & & $\mathrm{C}_{4}$ & $4(0-34)$ & $2(0-25)$ & $2(0-19)$ \\
\hline & & MPB & $6(0-41)$ & $3(0-35)$ & $2(0-26)$ \\
\hline & & Plk & $32(0-53)$ & $27(0-54)$ & $5(0-50)$ \\
\hline & \multirow[t]{3}{*}{ Mid } & $\mathrm{C}_{3}$ & $42(20-71)$ & $61(31-84)$ & $73(42-92)$ \\
\hline & & $\mathrm{C}_{4}$ & $3(0-29)$ & $2(0-22)$ & $2(0-17)$ \\
\hline & & MPB & $4(0-38)$ & $3(0-30)$ & $2(0-22)$ \\
\hline
\end{tabular}




\begin{tabular}{|c|c|c|c|c|c|c|}
\hline & & & Plk & $30(0-55)$ & $6(0-51)$ & $4(0-46)$ \\
\hline & & Upper & $\mathrm{C}_{3}$ & $40(17-69)$ & $53(28-81)$ & $72(40-91)$ \\
\hline & & & $\mathrm{C}_{4}$ & $3(0-31)$ & $2(0-23)$ & $2(0-18)$ \\
\hline & & & MPB & $5(0-40)$ & $3(0-32)$ & $2(0-23)$ \\
\hline & & & Plk & $33(0-54)$ & $29(0-54)$ & $4(0-47)$ \\
\hline L. equulus & Cocoa Ck & Lower & $\mathrm{C}_{3}$ & $22(1-36)$ & $28(8-45)$ & $33(15-57)$ \\
\hline & & & $\mathrm{C}_{4}$ & $22(0-38)$ & $17(0-34)$ & $3(0-30)$ \\
\hline & & & MPB & $23(0-38)$ & $20(0-37)$ & $4(0-36)$ \\
\hline & & & Plk & $21(0-39)$ & $26(0-42)$ & $27(0-46)$ \\
\hline & & & SG & $21(0-38)$ & $7(0-34)$ & $3(0-29)$ \\
\hline & & Mid & $\mathrm{C}_{3}$ & $27(8-45)$ & $34(14-55)$ & $45(21-70)$ \\
\hline & & & $\mathrm{C}_{4}$ & $11(0-35)$ & $3(0-31)$ & $2(0-24)$ \\
\hline & & & MPB & $21(0-36)$ & $6(0-36)$ & $3(0-33)$ \\
\hline & & & Plk & $25(0-41)$ & $25(0-46)$ & $27(0-50)$ \\
\hline & & & SG & $10(0-34)$ & $3(0-30)$ & $2(0-24)$ \\
\hline & Crab Ck & Upper & $\mathrm{C}_{3}$ & $28(10-48)$ & $37(17-60)$ & $48(25-74)$ \\
\hline & & & $\mathrm{C}_{4}$ & $5(0-33)$ & $3(0-29)$ & $2(0-22)$ \\
\hline & & & MPB & $14(0-36)$ & $4(0-36)$ & $2(0-30)$ \\
\hline & & & Plk & $27(0-43)$ & $29(0-47)$ & $6(0-50)$ \\
\hline & & & SG & $5(0-33)$ & $3(0-28)$ & $2(0-21)$ \\
\hline & Doughboy Ck & Lower & $\mathrm{C}_{3}$ & $42(16-67)$ & $50(26-80)$ & $69(38-90)$ \\
\hline & & & $\mathrm{C}_{4}$ & $3(0-32)$ & $2(0-23)$ & $2(0-19)$ \\
\hline & & & MPB & $4(0-40)$ & $3(0-34)$ & $2(0-23)$ \\
\hline & & & Plk & $32(0-54)$ & $33(0-54)$ & $5(0-48)$ \\
\hline & & Mid & $\mathrm{C}_{3}$ & $43(19-71)$ & $56(29-83)$ & $72(43-92)$ \\
\hline & & & $\mathrm{C}_{4}$ & $3(0-29)$ & $2(0-22)$ & $1(0-17)$ \\
\hline & & & MPB & $4(0-39)$ & $3(0-31)$ & $2(0-22)$ \\
\hline & & & Plk & $32(0-55)$ & $11(0-53)$ & $4(0-44)$ \\
\hline & & Upper & $\mathrm{C}_{3}$ & $48(23-76)$ & $64(34-87)$ & $76(48-93)$ \\
\hline & & & $\mathrm{C}_{4}$ & $3(0-26)$ & $2(0-20)$ & $1(0-15)$ \\
\hline & & & MPB & $3(0-37)$ & $2(0-27)$ & $2(0-20)$ \\
\hline
\end{tabular}




\begin{tabular}{|c|c|c|c|c|c|c|c|}
\hline & & \multirow{13}{*}{ Hell Hole } & \multirow{5}{*}{ Lower } & Plk & $34(0-54)$ & $8(0-51)$ & $4(0-41)$ \\
\hline & & & & $\mathrm{C}_{3}$ & $39(16-66)$ & $52(25-81)$ & $69(36-90)$ \\
\hline & & & & $\mathrm{C}_{4}$ & $3(0-32)$ & $2(0-25)$ & $2(0-19)$ \\
\hline & & & & MPB & $5(0-40)$ & $3(0-34)$ & $2(0-25)$ \\
\hline & & & & Plk & $30(0-54)$ & $26(0-54)$ & $5(0-49)$ \\
\hline & & & \multirow[t]{4}{*}{ Mid } & $\mathrm{C}_{3}$ & $37(16-65)$ & $50(26-78)$ & $66(36-89)$ \\
\hline & & & & $\mathrm{C}_{4}$ & $4(0-33)$ & $2(0-25)$ & $2(0-19)$ \\
\hline & & & & MPB & $4(0-41)$ & $3(0-34)$ & $2(0-26)$ \\
\hline & & & & Plk & $29(0-53)$ & $35(0-53)$ & $5(0-49)$ \\
\hline & & & \multirow[t]{4}{*}{ Upper } & $\mathrm{C}_{3}$ & $44(19-72)$ & $60(30-84)$ & $73(44-92)$ \\
\hline & & & & $\mathrm{C}_{4}$ & $3(0-29)$ & $2(0-22)$ & $1(0-17)$ \\
\hline & & & & MPB & $4(0-38)$ & $2(0-30)$ & $2(0-20)$ \\
\hline & & & & Plk & $35(0-54)$ & $5(0-53)$ & $4(0-45)$ \\
\hline & & \multirow[t]{12}{*}{ Mud Ck } & \multirow[t]{4}{*}{ Lower } & $\mathrm{C}_{3}$ & $38(15-64)$ & $46(23-75)$ & $65(33-88)$ \\
\hline & & & & $\mathrm{C}_{4}$ & $4(0-34)$ & $2(0-26)$ & $2(0-20)$ \\
\hline & & & & MPB & $5(0-41)$ & $3(0-36)$ & $2(0-27)$ \\
\hline & & & & Plk & $33(0-53)$ & $34(0-54)$ & $5(0-52)$ \\
\hline & & & \multirow[t]{4}{*}{ Mid } & $\mathrm{C}_{3}$ & $53(27-81)$ & $70(40-90)$ & $79(55-95)$ \\
\hline & & & & $\mathrm{C}_{4}$ & $2(0-23)$ & $1(0-18)$ & $1(0-14)$ \\
\hline & & & & MPB & $3(0-33)$ & $2(0-23)$ & $1(0-17)$ \\
\hline & & & & Plk & $29(0-53)$ & $5(0-48)$ & $3(0-35)$ \\
\hline & & & \multirow[t]{4}{*}{ Upper } & $\mathrm{C}_{3}$ & $48(25-79)$ & $71(38-89)$ & $76(53-95)$ \\
\hline & & & & $\mathrm{C}_{4}$ & $2(0-25)$ & $2(0-18)$ & $1(0-15)$ \\
\hline & & & & MPB & $3(0-35)$ & $2(0-25)$ & $2(0-18)$ \\
\hline & & & & Plk & $34(0-53)$ & $5(0-48)$ & $3(0-36)$ \\
\hline \multirow[t]{6}{*}{ Dry season } & \multirow[t]{6}{*}{ P. merguiensis } & \multirow[t]{6}{*}{ Cocoa Ck } & \multirow[t]{5}{*}{ Lower } & $\mathrm{C}_{3}$ & $21(1-34)$ & $25(5-41)$ & $28(10-48)$ \\
\hline & & & & $\mathrm{C}_{4}$ & $23(0-38)$ & $21(0-36)$ & $5(0-33)$ \\
\hline & & & & MPB & $24(0-39)$ & $20(0-37)$ & $10(0-37)$ \\
\hline & & & & Plk & $23(0-39)$ & $25(0-41)$ & $24(0-43)$ \\
\hline & & & & SG & $24(0-39)$ & $21(0-35)$ & $5(0-33)$ \\
\hline & & & Mid & $\mathrm{C}_{3}$ & $23(2-37)$ & $27(7-44)$ & $33(12-53)$ \\
\hline
\end{tabular}




\begin{tabular}{|c|c|c|c|c|c|}
\hline & & $\mathrm{C}_{4}$ & $22(0-37)$ & $9(0-35)$ & $4(0-32)$ \\
\hline & & MPB & $22(0-38)$ & $22(0-37)$ & $4(0-37)$ \\
\hline & & Plk & $24(0-39)$ & $25(0-42)$ & $27(0-45)$ \\
\hline & & SG & $24(0-37)$ & $11(0-34)$ & $3(0-31)$ \\
\hline & Upper & $\mathrm{C}_{3}$ & $28(7-45)$ & $32(13-53)$ & $38(18-62)$ \\
\hline & & $\mathrm{C}_{4}$ & $18(0-35)$ & $3(0-32)$ & $3(0-27)$ \\
\hline & & MPB & $20(0-37)$ & $4(0-36)$ & $4(0-35)$ \\
\hline & & Plk & $25(0-42)$ & $27(0-45)$ & $29(0-48)$ \\
\hline & & SG & $8(0-34)$ & $3(0-31)$ & $2(0-26)$ \\
\hline Crab Ck & Lower & $\mathrm{C}_{3}$ & $28(8-46)$ & $31(13-54)$ & $39(19-63)$ \\
\hline & & $\mathrm{C}_{4}$ & $16(0-34)$ & $5(0-32)$ & $3(0-27)$ \\
\hline & & MPB & $19(0-37)$ & $5(0-36)$ & $3(0-35)$ \\
\hline & & Plk & $25(0-42)$ & $27(0-46)$ & $28(0-48)$ \\
\hline & & SG & $6(0-34)$ & $3(0-30)$ & $2(0-27)$ \\
\hline & Mid & $\mathrm{C}_{3}$ & $26(5-42)$ & $31(11-50)$ & $35(16-58)$ \\
\hline & & $\mathrm{C}_{4}$ & $18(0-35)$ & $4(0-33)$ & $3(0-29)$ \\
\hline & & MPB & $19(0-37)$ & $11(0-37)$ & $4(0-36)$ \\
\hline & & Plk & $24(0-41)$ & $26(0-43)$ & $28(0-47)$ \\
\hline & & SG & $22(0-35)$ & $4(0-33)$ & $3(0-29)$ \\
\hline & Upper & $\mathrm{C}_{3}$ & $22(3-38)$ & $27(8-45)$ & $32(13-54)$ \\
\hline & & $\mathrm{C}_{4}$ & $22(0-36)$ & $10(0-34)$ & $3(0-31)$ \\
\hline & & MPB & $21(0-38)$ & $20(0-37)$ & $3(0-36)$ \\
\hline & & Plk & $23(0-40)$ & $24(0-42)$ & $27(0-45)$ \\
\hline & & SG & $21(0-36)$ & $9(0-34)$ & $3(0-31)$ \\
\hline Doughboy Ck & Mid & $\mathrm{C}_{3}$ & $32(7-53)$ & $37(13-61)$ & $41(21-71)$ \\
\hline & & $\mathrm{C}_{4}$ & $19(0-40)$ & $8(0-35)$ & $3(0-29)$ \\
\hline & & MPB & $25(0-44)$ & $6(0-41)$ & $4(0-38)$ \\
\hline & & Plk & $29(0-51)$ & $31(0-53)$ & $32(0-54)$ \\
\hline & Upper & $\mathrm{C}_{3}$ & $40(15-65)$ & $48(23-75)$ & $55(30-84)$ \\
\hline & & $\mathrm{C}_{4}$ & $4(0-33)$ & $3(0-26)$ & $2(0-22)$ \\
\hline & & MPB & $4(0-41)$ & $4(0-36)$ & $3(0-31)$ \\
\hline
\end{tabular}




\begin{tabular}{|c|c|c|c|c|c|}
\hline & & Plk & $31(0-54)$ & $31(0-54)$ & $5(0-52)$ \\
\hline \multirow[t]{12}{*}{ Hell Hole } & \multirow[t]{4}{*}{ Lower } & $\mathrm{C}_{3}$ & $27(2-43)$ & $32(7-52)$ & $37(11-60)$ \\
\hline & & $\mathrm{C}_{4}$ & $29(1-46)$ & $22(0-40)$ & $8(0-36)$ \\
\hline & & MPB & $28(0-47)$ & $27(0-43)$ & $14(0-42)$ \\
\hline & & Plk & $28(0-48)$ & $28(0-51)$ & $30(0-53)$ \\
\hline & \multirow[t]{4}{*}{ Mid } & $\mathrm{C}_{3}$ & $38(15-64)$ & $43(22-74)$ & $53(28-83)$ \\
\hline & & $\mathrm{C}_{4}$ & $4(0-34)$ & $3(0-28)$ & $2(0-22)$ \\
\hline & & MPB & $5(0-41)$ & $4(0-37)$ & $3(0-31)$ \\
\hline & & Plk & $32(0-53)$ & $32(0-54)$ & $7(0-54)$ \\
\hline & \multirow[t]{4}{*}{ Upper } & $\mathrm{C}_{3}$ & $53(27-82)$ & $67(36-88)$ & $76(48-93)$ \\
\hline & & $\mathrm{C}_{4}$ & $2(0-24)$ & $2(0-19)$ & $1(0-16)$ \\
\hline & & MPB & $3(0-34)$ & $2(0-25)$ & $2(0-20)$ \\
\hline & & Plk & $15(0-53)$ & $5(0-49)$ & $4(0-41)$ \\
\hline \multirow[t]{12}{*}{ Mud Ck } & \multirow[t]{4}{*}{ Lower } & $\mathrm{C}_{3}$ & $33(10-56)$ & $37(16-65)$ & $47(23-75)$ \\
\hline & & $\mathrm{C}_{4}$ & $14(0-38)$ & $5(0-33)$ & $3(0-27)$ \\
\hline & & MPB & $24(0-43)$ & $4(0-41)$ & $3(0-37)$ \\
\hline & & Plk & $30(0-52)$ & $30(0-54)$ & $33(0-54)$ \\
\hline & \multirow[t]{4}{*}{ Mid } & $\mathrm{C}_{3}$ & $38(13-63)$ & $45(21-73)$ & $53(29-82)$ \\
\hline & & $\mathrm{C}_{4}$ & $3(0-34)$ & $3(0-28)$ & $2(0-22)$ \\
\hline & & MPB & $4(0-41)$ & $4(0-38)$ & $3(0-33)$ \\
\hline & & Plk & $32(0-54)$ & $33(0-54)$ & $6(0-53)$ \\
\hline & \multirow[t]{4}{*}{ Upper } & $\mathrm{C}_{3}$ & $49(25-79)$ & $68(34-87)$ & $76(46-93)$ \\
\hline & & $\mathrm{C}_{4}$ & $2(0-24)$ & $2(0-19)$ & $2(0-17)$ \\
\hline & & MPB & $3(0-35)$ & $2(0-27)$ & $2(0-21)$ \\
\hline & & Plk & $9(0-54)$ & $5(0-51)$ & $4(0-42)$ \\
\hline \multirow[t]{6}{*}{ Sandfly } & \multirow[t]{4}{*}{ Lower } & $\mathrm{C}_{3}$ & $24(1-40)$ & $28(3-47)$ & $34(9-56)$ \\
\hline & & $\mathrm{C}_{4}$ & $29(1-49)$ & $25(0-43)$ & $16(0-38)$ \\
\hline & & MPB & $28(0-49)$ & $26(0-45)$ & $22(0-43)$ \\
\hline & & Plk & $27(0-48)$ & $27(0-51)$ & $30(0-51)$ \\
\hline & \multirow[t]{2}{*}{ Mid } & $\mathrm{C}_{3}$ & $25(2-42)$ & $31(5-49)$ & $34(11-59)$ \\
\hline & & $\mathrm{C}_{4}$ & $29(1-47)$ & $25(0-41)$ & $11(0-37)$ \\
\hline
\end{tabular}




\begin{tabular}{|c|c|c|c|c|c|c|}
\hline & & & MPB & $28(0-48)$ & $28(0-45)$ & $14(0-42)$ \\
\hline & & & Plk & $28(0-49)$ & $29(0-51)$ & $30(0-53)$ \\
\hline & & Upper & $\mathrm{C}_{3}$ & $28(4-47)$ & $32(9-56)$ & $38(15-64)$ \\
\hline & & & $\mathrm{C}_{4}$ & $28(1-44)$ & $16(0-38)$ & $4(0-33)$ \\
\hline & & & MPB & $27(0-45)$ & $19(0-43)$ & $4(0-40)$ \\
\hline & & & Plk & $28(0-49)$ & $29(0-52)$ & $31(0-54)$ \\
\hline A. vachellii & Cocoa Ck & Lower & $\mathrm{C}_{3}$ & $18(1-34)$ & $26(7-43)$ & $32(13-55)$ \\
\hline & & & $\mathrm{C}_{4}$ & $23(0-38)$ & $19(0-35)$ & $3(0-32)$ \\
\hline & & & MPB & $22(0-38)$ & $21(0-37)$ & $4(0-36)$ \\
\hline & & & Plk & $22(0-39)$ & $24(0-41)$ & $28(0-46)$ \\
\hline & & & SG & $24(0-38)$ & $11(0-34)$ & $3(0-31)$ \\
\hline & & Upper & $\mathrm{C}_{3}$ & $27(7-43)$ & $32(14-54)$ & $42(20-67)$ \\
\hline & & & $\mathrm{C}_{4}$ & $21(0-35)$ & $4(0-32)$ & $2(0-26)$ \\
\hline & & & MPB & $19(0-37)$ & $4(0-36)$ & $3(0-33)$ \\
\hline & & & Plk & $24(0-41)$ & $27(0-45)$ & $29(0-50)$ \\
\hline & & & SG & $17(0-35)$ & $3(0-31)$ & $2(0-24)$ \\
\hline & Crab Ck & Lower & $\mathrm{C}_{3}$ & $42(21-66)$ & $59(30-80)$ & $70(42-88)$ \\
\hline & & & $\mathrm{C}_{4}$ & $2(0-25)$ & $2(0-19)$ & $1(0-16)$ \\
\hline & & & MPB & $3(0-34)$ & $2(0-26)$ & $2(0-20)$ \\
\hline & & & Plk & $26(0-49)$ & $6(0-48)$ & $4(0-39)$ \\
\hline & & & SG & $2(0-24)$ & $2(0-18)$ & $1(0-15)$ \\
\hline & & Mid & $\mathrm{C}_{3}$ & $30(11-51)$ & $39(19-64)$ & $54(27-76)$ \\
\hline & & & $\mathrm{C}_{4}$ & $4(0-33)$ & $2(0-27)$ & $2(0-21)$ \\
\hline & & & MPB & $13(0-37)$ & $3(0-35)$ & $3(0-29)$ \\
\hline & & & Plk & $27(0-44)$ & $29(0-47)$ & $5(0-50)$ \\
\hline & & & SG & $3(0-32)$ & $3(0-27)$ & $2(0-20)$ \\
\hline & Hell Hole & Mid & $\mathrm{C}_{3}$ & $36(13-62)$ & $45(23-75)$ & $65(34-87)$ \\
\hline & & & $\mathrm{C}_{4}$ & $4(0-34)$ & $3(0-27)$ & $2(0-19)$ \\
\hline & & & MPB & $5(0-41)$ & $4(0-37)$ & $2(0-27)$ \\
\hline & & & Plk & $31(0-53)$ & $32(0-55)$ & $6(0-51)$ \\
\hline & Mud Ck & Lower & $\mathrm{C}_{3}$ & $50(25-80)$ & $71(39-90)$ & $78(57-95)$ \\
\hline
\end{tabular}




\begin{tabular}{|c|c|c|c|c|c|c|}
\hline & & & $\mathrm{C}_{4}$ & $2(0-23)$ & $2(0-18)$ & $1(0-15)$ \\
\hline & & & MPB & $3(0-34)$ & $2(0-24)$ & $1(0-18)$ \\
\hline & & & Plk & $31(0-54)$ & $5(0-47)$ & $3(0-31)$ \\
\hline & Sandfly & Lower & $\mathrm{C}_{3}$ & $37(13-62)$ & $45(21-75)$ & $62(34-86)$ \\
\hline & & & $\mathrm{C}_{4}$ & $6(0-35)$ & $3(0-27)$ & $2(0-21)$ \\
\hline & & & MPB & $8(0-41)$ & $4(0-37)$ & $2(0-29)$ \\
\hline & & & Plk & $31(0-53)$ & $33(0-55)$ & $5(0-50)$ \\
\hline & & Mid & $\mathrm{C}_{3}$ & $37(13-62)$ & $46(22-75)$ & $63(34-87)$ \\
\hline & & & $\mathrm{C}_{4}$ & $7(0-35)$ & $3(0-27)$ & $2(0-20)$ \\
\hline & & & MPB & $6(0-41)$ & $3(0-37)$ & $2(0-27)$ \\
\hline & & & Plk & $31(0-53)$ & $33(0-54)$ & $6(0-50)$ \\
\hline & & Upper & $\mathrm{C}_{3}$ & $34(9-56)$ & $42(18-69)$ & $54(28-81)$ \\
\hline & & & $\mathrm{C}_{4}$ & $19(0-38)$ & $3(0-31)$ & $2(0-23)$ \\
\hline & & & MPB & $17(0-43)$ & $4(0-39)$ & $2(0-32)$ \\
\hline & & & Plk & $30(0-52)$ & $34(0-54)$ & $21(0-53)$ \\
\hline L. equulus & Cocoa Ck & Lower & $\mathrm{C}_{3}$ & $28(7-44)$ & $33(13-55)$ & $44(22-69)$ \\
\hline & & & $\mathrm{C}_{4}$ & $20(0-35)$ & $3(0-31)$ & $2(0-25)$ \\
\hline & & & MPB & $20(0-37)$ & $3(0-36)$ & $3(0-33)$ \\
\hline & & & Plk & $23(0-41)$ & $27(0-46)$ & $28(0-49)$ \\
\hline & & & SG & $11(0-34)$ & $3(0-30)$ & $2(0-24)$ \\
\hline & & Mid & $\mathrm{C}_{3}$ & $39(19-65)$ & $57(27-78)$ & $66(43-86)$ \\
\hline & & & $\mathrm{C}_{4}$ & $3(0-27)$ & $2(0-21)$ & $1(0-16)$ \\
\hline & & & MPB & $3(0-35)$ & $2(0-29)$ & $2(0-22)$ \\
\hline & & & Plk & $29(0-48)$ & $7(0-49)$ & $4(0-39)$ \\
\hline & & & SG & $2(0-25)$ & $2(0-20)$ & $1(0-16)$ \\
\hline & Crab Ck & Mid & $\mathrm{C}_{3}$ & $45(23-69)$ & $62(32-82)$ & $70(47-88)$ \\
\hline & & & $\mathrm{C}_{4}$ & $2(0-24)$ & $2(0-19)$ & $1(0-15)$ \\
\hline & & & MPB & $3(0-33)$ & $2(0-26)$ & $2(0-19)$ \\
\hline & & & Plk & $28(0-49)$ & $4(0-47)$ & $3(0-37)$ \\
\hline & & & SG & $2(0-24)$ & $2(0-19)$ & $1(0-15)$ \\
\hline & & Upper & $\mathrm{C}_{3}$ & $34(15-56)$ & $42(22-70)$ & $62(32-83)$ \\
\hline
\end{tabular}




\begin{tabular}{|c|c|c|c|c|c|}
\hline & & SG & $3(0-30)$ & $2(0-23)$ & $1(0-18)$ \\
\hline \multirow[t]{4}{*}{ Doughboy Ck } & Upper & $\mathrm{C}_{3}$ & $56(28-82)$ & $70(42-91)$ & $79(58-95)$ \\
\hline & & $\mathrm{C}_{4}$ & $2(0-22)$ & $1(0-17)$ & $1(0-14)$ \\
\hline & & MPB & $3(0-32)$ & $2(0-24)$ & $1(0-17)$ \\
\hline & & Plk & $26(0-53)$ & $4(0-45)$ & $3(0-32)$ \\
\hline \multirow[t]{8}{*}{ Hell Hole } & Lower & $\mathrm{C}_{3}$ & $41(15-65)$ & $46(25-79)$ & $71(38-89)$ \\
\hline & & $\mathrm{C}_{4}$ & $3(0-33)$ & $2(0-25)$ & $2(0-19)$ \\
\hline & & MPB & $6(0-40)$ & $3(0-35)$ & $2(0-27)$ \\
\hline & & Plk & $32(0-54)$ & $29(0-54)$ & $5(0-48)$ \\
\hline & Mid & $\mathrm{C}_{3}$ & $61(32-85)$ & $75(47-93)$ & $80(62-96)$ \\
\hline & & $\mathrm{C}_{4}$ & $2(0-20)$ & $1(0-16)$ & $1(0-13)$ \\
\hline & & MPB & $2(0-29)$ & $2(0-20)$ & $1(0-16)$ \\
\hline & & Plk & $5(0-52)$ & $4(0-41)$ & $2(0-29)$ \\
\hline \multirow[t]{12}{*}{ Mud Ck } & Lower & $\mathrm{C}_{3}$ & $46(22-74)$ & $60(31-86)$ & $76(47-94)$ \\
\hline & & $\mathrm{C}_{4}$ & $3(0-28)$ & $2(0-20)$ & $2(0-16)$ \\
\hline & & MPB & $3(0-38)$ & $2(0-29)$ & $2(0-21)$ \\
\hline & & Plk & $31(0-54)$ & $5(0-52)$ & $3(0-41)$ \\
\hline & Mid & $\mathrm{C}_{3}$ & $63(34-86)$ & $76(47-94)$ & $83(64-96)$ \\
\hline & & $\mathrm{C}_{4}$ & $2(0-21)$ & $1(0-16)$ & $1(0-13)$ \\
\hline & & MPB & $2(0-28)$ & $2(0-20)$ & $1(0-15)$ \\
\hline & & Plk & $5(0-50)$ & $4(0-42)$ & $2(0-25)$ \\
\hline & Upper & $\mathrm{C}_{3}$ & $78(58-95)$ & $85(70-97)$ & $90(76-98)$ \\
\hline & & $\mathrm{C}_{4}$ & $1(0-14)$ & $1(0-11)$ & $1(0-9)$ \\
\hline & & MPB & $1(0-18)$ & $1(0-13)$ & $1(0-11)$ \\
\hline & & Plk & $3(0-31)$ & $2(0-21)$ & $1(0-15)$ \\
\hline \multirow[t]{3}{*}{ Sandfly } & Lower & $\mathrm{C}_{3}$ & $30(3-47)$ & $35(12-58)$ & $43(19-71)$ \\
\hline & & $\mathrm{C}_{4}$ & $26(1-43)$ & $14(0-37)$ & $3(0-29)$ \\
\hline & & MPB & $28(0-45)$ & $7(0-43)$ & $4(0-38)$ \\
\hline
\end{tabular}




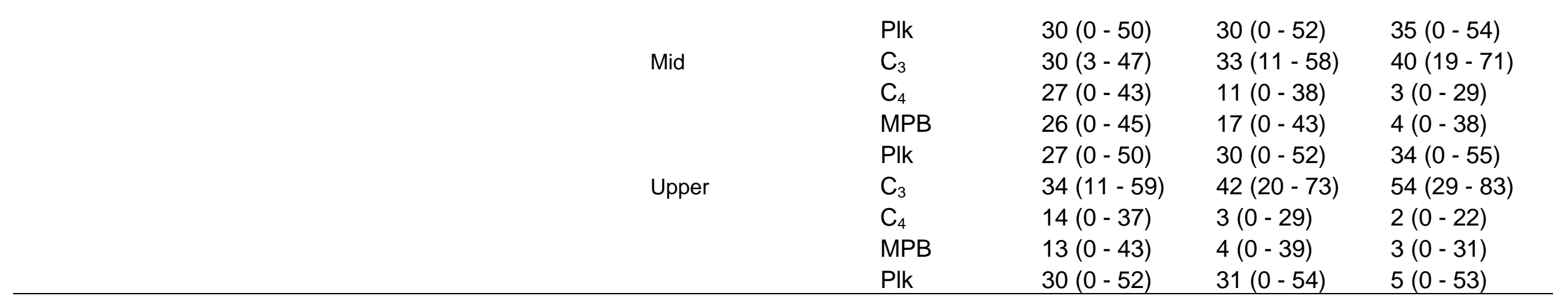

